DOI No: http://dx.doi.org/10.29228/Joh.43290

Makale Türü: Araştırma makalesi

Geliş Tarihi: 01.05.2020

Kabul Tarihi: 08.06.2020

On-line Yayın: 31.08.2020
Article Type: Research article

Submitted: 01.05 .2020

Accepted: 08.06.2020

Published Online: 31.08.2020

Atıf Bilgisi / Reference Information

İstek, E. (2020). Anadolu Kervan Yollarında Karşılaşılan Problemler ve Yol Güvenliği (17. YY.). Journal of History School, 47, 2085-2116.

\title{
ANADOLU KERVAN YOLLARINDA KARŞILAŞILAN PROBLEMLER VE YOL GÜVENLİĞİ (17. YY.)
}

\section{Emrah İSTEK ${ }^{1}$}

\section{$\ddot{\mathbf{O} z}$}

Anadolu'da hâkimiyet kuran devletler ile bu coğrafyayı diğer bölgelere geçiş güzergâhı olarak kullanan imparatorluklar, Anadolu yollarının gelişimine önemli katkılar sağladılar. Eski çağlardan Selçuklulara kadar yatırım yapılan yol ağı, Anadolu Selçukluları döneminde inşa edilen onlarca kervansaray ve hanlarla birlikte güvenlik noktasında da iyi bir seviyeye ulaştı. Osmanlı Devleti ise hem ticaretinin aksamaması hem de ülkeler ötesi sefer lojistiği için söz konusu yollarda kurduğu derbend ve menzil teşkilatları vasıtasıyla yol güvenliği ve bakımını sistematik bir temele oturturdu. Bütün bu çaba ve önlemlere rağmen dönemin ağır taşıma araçları olan develer ve diğer hayvanlarla birlikte sayıları binleri bulan kervanlar, yollarda hırsızlık ve yağma başta olmak üzere can ve mal korkusu içinde zorlu rotaları takip etmekteydiler. Bu sorunların yanı sıra gece yolculukları, dar geçitler, bozuk yollar ve mevsimsel problemler yolculuklarda karşılaşılan diğer tehlikelerdi.

Anahtar Kelimeler: Anadolu, Yol Güvenliği, Kervan, Seyyah.

${ }^{1}$ Dr. Öğr. Üyesi, Ağrı İbrahim Çeçen Üniversitesi, Fen Edebiyat Fakültesi, Tarih Bölümü, Yeniçağ Tarihi Anabilim Dal1, eistek@agri.edu.tr, Orcid: 0000-0003-1407-3609 


\title{
Problems Encountered On Anatolıan Carvan Routes And Route Safety (17th Century)
}

\begin{abstract}
From the dominant states in Anatolia to the empires that used this geography as a transition to other regions, many dominant powers developed Anatolian roads over time. The road network, which was built from ancient times to the Seljuks, reached a good level in the security point with tens of caravanserais and inns built during the Anatolian Seljuks. The Ottoman Empire, on the other hand, has placed road safety and maintenance on a systematic basis, both through the mountain pass (derbend) and destination (menzil) organizations for non-stop trade and for cross-country logistics. Despite all these efforts and measures, caravans, where camels and other animals, which were the heavy transport vehicles of the period and the caravans reaching their numbers thousands were following difficult routes in fear of life and property, especially theft and looting on the roads. In addition to these problems, night trips, narrow passages, rough roads and seasonal problems were other dangers encountered in the trips.
\end{abstract}

Keywords: Anatolia, Route Safety, Caravan, Traveler.

\section{GİRIŞ}

Yol ülkelerin gelişmişliğinin bir göstergesi olduğu gibi medeniyet inşasının da köşe taşlarındandır. Anadolu yolları, Lidyalıların bölge ticaretini canlandırmak ve güvenlik kaygılarını azaltmak maksadıyla kurdukları Kral Yolu, Romalıların ticari ve siyasi birliğini sağlamak gayesiyle inşa ettikleri yollar, iki dünyayı kavuşturan ipek ve baharat yolları ve hacıları kutsal mekânlara kavuşturan yollar bölgedeki yol ağının merkezi ve çeșitli bir yapıda olduğunu göstermektedir. Doğu ve Batı medeniyetini sentezleyerek müstesna bir medeniyet inşa eden Osmanlı Devleti de birçok kadim imparatorluğun yaptığ 1 gibi kendinden önceki yollara yeni menziller eklemek suretiyle Anadolu yol ağını çeşitlendirdi. Örneğin Bursa'nın fethinden sonra kadim İpek yolunun AnadoluKaradeniz bağlantısı Bursa'ya kaydı ve bu güzergâh zaman içinde gelişerek Anadolu yol ağının ana unsurlarından biri oldu (Tabakoğlu, 2014: 370).

Yol güvenliğinin ana unsurlarından birisi ortalama birer günlük mesafelerde yol üzerlerinde kurulan menzillerdi. "Konak", "konak yeri" veya "bir günlük yol" anlamlarına gelen menziller, yolların güvenliği, kervanların konaklaması, ulakların dinlenmesi veya at değiştirmesi, sefere giden askerlerin ihtiyaçlarının karşılanması gibi vazifelerini icra etmekteydiler (Sak, Çetin, 2004: 180). Genellikle kervansarayların bulunduğu yerlerde kurulan ve çeşitli askeri, sosyal ve ticari eserlerle gelişen menziller geliştikleri oranda da yolun güvenli olmasında aktif rol oynamaktaydı. Zamanla büyüyen menzil merkezlerindeki 
güvenlik derbend ${ }^{2}$ teşkilatlarının bünyesinde sağlanmaktaydı (Müderrisoğlu, 2002:920). Menziller vasitasıyla sağlanan hızlı haberleşme sistemi de yollarda ortaya çıkan olumsuz durumların merkeze veya ilgili kurumlara ivedi olarak iletilmesini sağlamaktaydı. Ancak 2. Viyana Kuşatması sonrasında ortaya çıkan eşkıyalık faaliyetleri ve üç cephede yaşanan savaşlar hem ulakların sayılarının artmasına hem de buna bağlı olarak keyfi hareket etmelerine sebep olmuştu. (Sak, Çetin, 2004: 183-187).

Tüccar, maceracı, din adamı veya sefir gibi kimliklerle yola çıkan seyyahların yolları iyi bilenler sınıfina girdikleri kabul edilmelidir. Yolların kullanılma sıklığı ile güvenli olup olmadığı birbirine doğru orantılı olduğundan, kendi güvenlik kaygısıyla yolun durumunu önemseyen ve ona göre yola revan olan seyyahlar, yol güvenliği konusunda başvurulacak kaynaklardan biridir. $\mathrm{Bu}$ bağlamda 17. yüzyılda Osmanlı Devleti'nin Anadolu coğrafyasında yol güvenliğinin nasıl olduğu sorusuna büyük oranda seyahatnamelerin verdiği bilgiler doğrultusunda cevap aranmaktadır. Nitekim yolları en çok arşınlayanların başında gelen tacir ve seyyah vasfinı taşıyan J. B. Tavernier altı defa uzun seyahatlere çıkan birisi olarak bir yol uzmanı gibi görülebilir. Ayrıca bir eczacı olan Tournefort veya Anadolu'nun kiliselerini tek tek ziyaret etmek isteyen Polonyalı Simeon yolları ticaret maksadıyla gidip gelen bir tacir kadar tecrübe eden seyyahlardan sadece bazılarıdır.

Osmanlı Devleti’nin tüm Anadolu'yu hakimiyeti altına aldığı 16. yüzyılın ilk çeyreği, aynı zamanda bitmek tükenmek bilmeyen eşkıyalık faaliyetlerinin de başladığı dönem olarak kabul edilebilir. Zira Bozoklu Celal'in adını verdiği Celali eşkıyaları ${ }^{3}$ 17. yüzyılın sonlarına doğru ancak minimize edilebilmişti. Ayrica bu dönemde yaşanan Osmanli-Safevi mücadeleleri de Anadolu yol güvenliğini etkileyen unsurların başında gelmekteydi. Bir taraftan Anadolu'da çıkan isyan iklimi, diğer taraftan devletin diş mücadelelerle boğuşması sonucunda içeride oluşan yönetim boşlukları yolların güvenliğini de tehlikeye sokmaktaydı. Ancak her şeye rağmen ticari faaliyetlerin aksamaması gerekmekteydi. Nitekim bu dönemde Avrupa'dan gelerek doğuya veya güneye yolculuk yapan seyyahların varlı̆̆ söz konusu bölgede ticaretin veya diplomatik

\footnotetext{
${ }^{2}$ Menzillerin içinde kurulan derbenler haricinde, dar boğazlarda, önemli geçitlerde veya köprü yanlarında kurulan derbendler genellikle küçük bir kale şeklinde inşa edilmekteydi. Derbendlerin kurulacakları yerler de yolun tehlikesine ve önemine göre araştırılarak ve kaza yetkililerinin fikirleri alınarak tespit edilirdi. Derbend konusunda ayrıntılı bilgi için bk. http://www.pusulagazetesi.net/kose-yazilari/osmanlilarda_yol_emniyeti-1242.html (E.T. 07.06. 2020).

${ }^{3}$ Eşkıya tabiri için belgelerde "suhte", "harami", "ehl-i fesad" ve "levend" gibi ifadelerin de kullandığı görülmektedir (Kütükoğlu, 2018: 84).
} 
hareketliliğin devam ettiğini göstermektedir. Ayrıca her yıl aksatılmadan yapılan surre alaylarının muazzam kalabalıklar halinde gerçekleştirilmesi bu sürekliliğin diğer bir tezahürüdür.

Bu çalışmada Anadolu'nun sinırları, günümüz Türkiye'sinde İstanbul'un batısı olan ve "Trakya" olarak da adlandırılan kısmın haricinde kalan yerleri kapsamaktadır. Bunun yanında Üsküdar'dan başlamak suretiyle, doğuda İran sınırına kadar olan doğu sınırı ile güneyde gerek iklimsel gerekse yapısal farklılık arz eden Bağdat-Musul-Halep çizgisine kadarki güney sınırı esas alınmıştır. İstanbul-Edirne arasındaki ana yolun 17. yüzyılda padişahların Edirne'yi merkez gibi kullanmalarından ötürü oldukça işlek, güvenli ve bakımlı olması sebebiyle de Anadolu yol güvenliğinden ayrışacağı düşüncesi bu bölgenin araştırma dışında tutulmasının temel dayanağıdır. Sultanların kullandığı bu yola "İstanbul Caddesi" de denmekteydi (Müderrisoğlu, 2002:922). Basit bir örnek vermek gerekirse Anadolu yollarının çoğu yerinde arabalar kullanılamazken ${ }^{4}$ buradaki yolun yapısından dolayı arabalı yolculukların hayli ön planda olduğu göz ardı edilmemelidir. ${ }^{5}$

\section{Yol Güzergâhlarına Genel Bakış}

Batıdan üç kol halinde gelerek Edirne'den Anadolu'ya giren yollar İstanbul'da birleşmekteydi. İstanbul'dan tekrardan üçe ayrılarak Anadolu'yu geçen yollar ise sağ, orta ve sol kol olarak üç ana hattan oluşmaktaydı. Her üçünün de başlama noktası İstanbul (Üsküdar) olup gemiyle Marmara üzerinden Bursa'ya geçilir veya kara yoluyla Bolu'ya ve Bursa'ya ulaşılırdı. Marmara'nın doğusunda başlamak üzere ayrılan yolların kuzey Anadolu dağ sıralarını takip eden rotası sol; Ankara taraflarından iç Anadolu boyunca uzanan yol orta ve Torosları aşarak güneye inen yol ise sağ yol olarak genel kabul görmüştü. ${ }^{6}$

Bursa gerek Marmara'ya komşu olması gerekse de kadim bir Osmanlı kenti olması dolayısıyla söz konusu yol ağlarının önemli bir menziliydi. Buradan hem doğu hem de İzmir taraflarına kervanlar işlemekteydi. Thévenot'un Bursaİzmir arasında aktif olan kervan hakkında aktardığı; "Bursa'ya giderken her

4 İpek yolu üzerindeki yolların bazıları düz olduğundan tekerlekli araçların geçmesine imkân sağlamaktadır. Ancak yolların büyük bir kısmı kervan ulaşımına imkân sağlamaktadır (Tabakoğlu, 2014: 355).

${ }^{5}$ IV. Mehmed'in sık sık Edirne taraflarına gittiği dönemlerde kendisinin ve Valide Sultanın bu yolu kullandığı Abdurrahman Abdi Paşa'nın Vekayi'-namesi’ nde mükerreren aktarılan bir husustur (Abdurrahman, 2008: 114, 129, 147).

${ }^{6}$ Yol ağı konusunda detaylı malumat veren temel eserden birisi Franz Taeschner'in "Osmanl

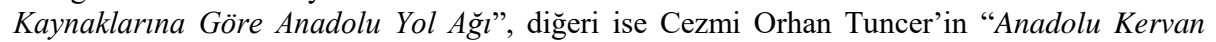
Yollart” adlı eserleridir. Bu eserler için bk. (Taeschner, 2010); (Tuncer, 2007). 
Perşembe Bursa'dan İzmir'e giden kervana katılmaya hazırlanmıştım; ama kente Perşembe günü epey geç vardiğım için sekiz gün beklemem gerekti..." ifadesine göre, kervanın haftada bir defa $^{7}$ İzmir istikametine hareket ettiği anlaşılmaktadır (Thévenot, 2009: 115). Bursa'dan doğuya giden diğer bir yol (Tournefort'un ${ }^{8}$ rotası) Ankara üzerinden Tokat'a oradan da Erzurum'a kadar uzanmaktaydı. Yine Tournefort'un takip ettiği diğer bir rota İstanbul'dan başlayarak Karadeniz sahil şeridi boyunca Trabzon'a, oradan da güneydoğuya inerek Erzurum'a ulaşmaktaydı. İstanbul ve Bursa/Bolu güzergâhını takip eden ve Kuzey Anadolu Dağlarının güneyi boyunca doğuya giden yol ise, Merzifon, Amasya, Tokat, Sivas üzerinden Erzurum'a kadar uzanmaktaydı. Bu yol Tavernier'in kaydettiği gibi İzmir, Afyon üzerinden Tokat'a bağlanmaktaydı. Erzurum'da yine iki kola ayrilan yolun biri kuzeye biri de doğuya ayrılmak suretiyle, iki koldan devam ederek Revan ve Van üzerinden İran topraklarına geçmekteydi.

Sivas'tan Kangal, Elbistan ve Malatya üzerinden güneye inen bir yol daha vardı ki fazla tercih edilmeyen güzergâhlar arasındaydı. Zira özellikle kış şartlarında çok zorlu yolculukların yapıldığı bu güzergâh, yaz aylarında da birçok eşkıyayla karşılaşma tehlikesini barındırmaktaydı. Antakya Patriği Makaryus (Macarius) bu rota hakkında malumat sahibi olmamıza yarayacak bilgiler vermektedir. Makaryus'un yol tarifinden ve çektikleri sıkıntılardan anlaşıldığına göre bu güzergâh hem engebeli bir yol yapısına sahip hem de özellikle kış döneminde dağ sırtlarındaki yüksek geçitleri aşma zorunluluğundan kaynaklanan problemlerle doluydu. Diğer bir tehlike Sivas'tan Amid ve oradan Muş'a giden Simeon'un belirttiği gibi dağları aşmada yaşanan yürüme zorluğuydu. Nitekim Harput-Ergani yolu üzerinde "Nal Kıran" adında ün salmış bir dağ 1 aştıktan sonra Simeon'un ayakkabıları tamamen parçalanmıştı. Bunların yanı sıra vadilerde karşılaşılan derin sulardan ancak yöre insanının sırtından geçilebilmesi de karşılaşılan diğer bir zorluktu (Simeon, 2016: 131, 138).

İzmir'den yola çıkan kervanlar Afyonkarahisar'dan itibaren güneye ve doğuya yönelmekteydiler (Tavernier, 2010: 126). Doğu'ya gidenler Tokat üzerinden İran'a geçerken; Konya ve Karaman üzerinden Torosları aşarak Adana'ya bağlanan güney güzergâhı ise Antakya çevresinden Halep'e oradan Urfa'ya uğrayarak Bağdat'a kadar uzanmaktaydı. Aynı yoldan daha da güneye inmek için kervanın Antakya'dan itibaren Şam yolunu takip etmesi gerekirdi ki

${ }^{7}$ Taeschner De la Boullaye-le-Gouz'a dayandırarak söz konusu kervanın haftada bir gittiğini teyit etmektedir (Taeschner, 2010: 207).

${ }^{8}$ Toornefort doğu seyahatine 17. yüzyılda başlamakla beraber daha çok 18. Yüzyılda seyahatlerini gerekleştiren bir seyyahtır. Bu çalışmanın konusu 17. yüzyıl olsa da Tournefort, Théevenot ve Tavernier gibi 17. yüzyıldaki Fransız seyyahların bir devamı niteliğinde görüldüğünden onun eseri de bu çalışmaya dâhil edilmiştir. 
böylece Kudüs'e, Kahire'ye veya Hicaz'a kadar uzanan kuzey-güney güzergâhı izlenmiş olurdu. Genel olarak Anadolu içinden geçen yolların kuzey ve güney sıra dağlarını takip ettikleri bilinmektedir. Anadolu'nun doğusuna kadar uzanan güney rotası daha doğuya gidilecekse Urfa'dan itibaren Diyarbekir, Batman, Bitlis ve Van Gölü çevresinden İran'a geçen rotayı takip etmek gerekmekteydi.

Yol ağı ile ilgili verilen bu bilgiler bu çalışmada hangi güzergâhlar üzerinde durulduğunun ipuçlarını verdiğinden bu kadarla iktifa edilecektir. Çünkü araştırmamızın konusu Anadolu yol ağını baştan sona tarif etmekten ziyade yollarda karşılaşılan problemlerin tespitidir.

\section{Yolculuk Çeşitleri ve Çekilen Sıkıntılar}

Bir kervan kafilesine katılarak yapılan yolculuk, güvenlik kaygısından dolayı en çok tercih edilen seyahat yöntemiydi. Bir kervana dâhil olmak öncelikle kalabalık bir insan grubuyla hareket etmek anlamına gelmesinden dolayı daha korunaklıydı. Ayrıca kervanın büyüklüğüyle doğru orantılı olan muhafız birlikleri, eşkıyalara veya vahşi hayvanlara karşı korunaklı bir yolculuk yapma imkânı sunmaktaydı. Kervan yolculuğunun avantajlarından bir diğeri ise tüccarlar veya diğer yolcularla fikir alışverişinde bulunma olanağıydı. Zira böylece bir tüccar için çevre edinmek, yeni ticari ilişkiler kurmak veya malını pazarlayacağı yer hakkında bilgi sahibi olmak fırsatını doğurmaktaydı.

Kervanla yapılan yolculuk her ne kadar güvenli olsa da, oldukça yavaş hareket edildiğinden alınması gereken yol da hayli uzun sürmekteydi. Bu yavaşlık kervanın kalabalık olmasıyla doğru orantılı olmakla beraber hayvanların türüyle de alakalıdır. Mesela deve kervanları, ucuz ancak yavaş hareket ederken, daha pahalıya patlayan atlardan müteşekkil bir kervan aynı mesafeyi daha hızlı almaktaydı (Tavernier, 2010: 144). Simeon İstanbul taraflarında genellikle atlarla seyahat yaptıklarını, Sivas ve Amid taraflarında ise merkep ${ }^{9}$ ve öküz kullanıldığını aktarmaktadır. Özellikle Sivas dolaylarında öküzlere tuz ve diğer eşyalar yüklendiğini hatta bu hayvanların binek hayvanı olarak da kullanıldığını gözlemlemiştir. Yine onun iddiasına göre atla yolculuk çok maliyetli olup, gasp edilme tehlikesi vardı. Nitekim kendi atı da birçok defa gasp edilmişti (Simeon, 2016: 130).

Yolculuklarda kullanılan hayvanların mahiyeti yolun yapısıyla da ilgilidir. Anadolu'nun dağlik bölgelerindeki bozuk ve engebeli yollar yolculukların uzamasının temel nedenlerinden biriydi. Osmanlı Devleti'nde yol yapımı, savaş zamanlarında sefer organizasyonunun bir parçası olarak görüldügünden, ordunun

${ }^{9}$ Orhonlu, Sahra'da özellikle develer tercih edilirken Kuzey Irak ve Anadolu'da eşeklerin arazi yapısından dolayı daha çok kullanıldığını belirtmiştir (Orhonlu, 1984: 143).

[2090] 
geçeceği yollar ivedilikle elden geçirilmekte ve gerekli yerler genişletilirken ihtiyaç olan yerlere de yeni köprüler kurulmaktayd $1 .{ }^{10}$ Derbendelerde olduğu gibi köprülerin kuruldukları yerlerde de bir bakıma yolun güvenliğini sağlamaktaydı (Kocaoğlu, 2020: 48). Çünkü köprü meremmetçiliği (bakımı) ve koruması belli vergi muafiyetleri çerçevesinde köprüye yakın yerdeki halk tarafından sağlanmaktaydı. Orhonlu'ya göre ordu için yapılan yolların haricinde yol yapımına veya tamirine yeterli önem verilmemekteydi (1990: 70). Yolların belli başlı yerlerinde kurulan derbend görevlileri veya meskûn olduğu bölgedeki yolun bakımını üstlenen ve bunun karşılığında bazı vergilerden muaf tutulan kimseler mevcutsa $\mathrm{da}^{11}$ uzun barış döneminde yolların tamiriyle yeteri kadar ilgilenilmediği hususu göz ardı edilmemelidir.

Kervan dışında tercih edilen bir diğer yolculuk yöntemi; aynı güzergâhı paylaşan insanların birbirleriyle anlaşmak suretiyle kendilerine eşlik edecek koruma askerler (Yeniçeriler) bularak hedefe varmalarıydı. Bu şekilde yapılan yolculukların ancak kısa mesafeler için uygun olduğu görülmektedir. Bu yöntem deve kervanlarıyla yolculuk yapmaya kıyasla oldukça hızlıdır. Nitekim Tavernier de Livorna'ya gidecek filonun birkaç gün daha gitmeyeceğini öğrenmesi üzerine bu kısa Efes seyahatine çıkmıştı. Seyyah bu türden bir yolculuğun ne kadar sürdüğünü şu şekilde aktarmaktadır: “...herhangi bir mal engeli olmaksızın yalnızca para taşıyan on-on iki kişilik bir kafilenin, atlı bir kervanin iki günde, deve kervanlarının dört günde ancak gideceği bir yolu bir günde alabileceğini belirtmek gerek." (Tavernier, 2010: 118).

Bazen de beklenen kervanın geç geleceği düşüncesi yolcuları kaldıkları kervansarayda beraber yola çıkacak birilerini bulma arayışına sokmaktaydı. Birkaç kişi olarak İskenderun'dan İstanbul'a gitmek isteyen Troilo, Adana'ya varmadan konakladığı bir kervansarayda İstanbul'a gitmek üzere gelecek bir kafileyi beklemiş ancak kimse gelmeyince ve yola yalnız devam etmenin tehlikeli olabileceğini anlayınca, beraber gidebileceği yol arkadaşları aramaya başlamıştı.

${ }^{10} \mathrm{Bu}$ konuda yüzlerce Mühimme hükmü bulmak mümkündür. Birkaç tanesini zikredecek olursak; I. Ahmed döneminde Osmanlı-İran arasındaki devam eden savaşta ordunun geçeceği yerlerin Konya'ya kadarki kısmının top arabaları için elden geçirilmesi ve yollardaki bozuk kısımlarım tamir edilmesi istenmiştir (BOA. A.DVNSMHM.d., 79, 722). Bir başka İran seferi olan Bağdat (1638) seferi öncesinde de İznikmid sancakbeyine yollanan hükümde, ordunun geçeceği yolların düzeltilip köprülerin de tamir edilmesi istenmiştir (BOA. A.DVNSMHM.d., 88, 318). Bağdat seferinden bir sene evvel (1637) Diyarbekir taraflarına top mühimmatının nakledilmesi planlanmış, söz konusu topların geçeceği yolların tamiratı emredilmiştir (BOA. A.DVNSMHM.d., 87, 238).

${ }^{11}$ Erzurum Halep üzerindeki Divriği’ye bağlı Burma Derbendi'nin yollarının Ali adında bir zata bırakılmış, bunun karşılığına bu kişi tekâlif vergisinden muaf tutulmuştur. Hatta Ali Efendi yaşlanınca bu görev oğlu Himmet’e devredilmiştir (Orhonlu, 1990: 71). 
Kervansarayda iki kölesi olan bir Ağa ile karşılaşan seyyah bu kişilere sorduktan ve onlara güven duyduktan sonra birlikte yola çıkmaya karar vermişti. Yolculuğa gece çıkan Troilo ve diğerleri, İskenderun'dan gelen İngiliz ve Hollandalı birçok tüccarın bulunduğu kalabalık bir kervanla yolculuk esnasında karşılaşarak onlara dahil olmuşlardı (Troilo, 1676: 482).

Seyahat etmek için en güvenli yollardan biri de tesadüfi veya planlanmış olarak devlet erkanın bulunduğu bir kafileyle yola çıkmaktı. Bu şekilde bir yolculuk daha güvenli olmasının yanında yolcuya prestij de kazandırmaktaydı. Nitekim Troilo İskenderun'dan Adana'ya kadar çektiği sıkıntıları İstanbul'a kadar çekmemek için, Adana'da karşılaştığ 1 bir paşadan ${ }^{12}$ kendilerini de İstanbul'a kadar götürmelerini rica etmiş ve ricası karşılık bulmuştu (Troilo, 1676: 490). Aynı şekilde Tournefort, Erzurum Valisi olarak atanan Köprülü Numan Paşayla yolculuk yapmayı çok büyük bir firsat olarak görmüştü (Tournefort, II, 2005: 101). Paşayla yolculuk etmenin güvenli olduğunu başkaları da duymuş olmalı ki çevre illerden paşanın kervanına katılmak için birçok insanın da dâhil olduğuna şahit olmaktaydı. Seyyaha göre bu güvenin sebebi paşanın geçtiği yerlerde yakaladığı soyguncuların kellesini almasıydı (Tournefort, II, 2005: 123).

Devlet erkânıyla yapılan yolculukların da kendine göre olumsuz tarafları bulunmaktaydı. Örneğin, Troilo'nun iddiasına göre kafilesine katıldığı Paşa İstanbul'a giderken, beklenmedik bir şekilde bu rotadan çıkarak İzmir yoluna sapmıştı (Troilo, 1676: 499-500). Ayrıca bu yol ayrımına kadar da ana yoldan gitmektense köylerin içlerinden geçmeyi tercih ederek yolu uzatmış, askerler ise köylerde ne var ne yoksa talan etmişlerdi. Bu yolla yapılan seyahatlerde bile hırsızlık hadiselerine rastlanmaktaydı. Zira paşanın uğradığı bir köyde çadırlardan birisine giren hırsız bütün eşyayı çalmış, buna kızan Paşa çalınan malın hepsini bulmakla kalmamış, köylüden çok daha fazlasını tahsil etmişti (Troilo, 1676: 491-495). Doğruluğu tespit edilemeyen bu hırsızlık hadisesinin yaşanmış olması olumsuz bir durum gibi görünmekle beraber, bu hadiseden çıkartılacak sonuç; bir taraftan devlet erkânıyla yapılan yolculuk esnasında yaşanan problemlerin ertelenmeden olay mahallinde çözülmesi, diğer taraftan adeta bir devlet garantisi altında yolculuk yapılmasıdır.

${ }^{12}$ Seyyah isim belirtmediğinden bahsi geçen paşanın kim olduğu bilinmemektedir. Paşalık unvanı -seyahatnamedeki ifadeye göre- taşıdığına göre en azından vezaret makamında birisi olabilir. 


\section{Gece ve Gündüz Yolculukları ile İklim Şartları}

Kervan yolculukları havanın ve mevsimin durumuna göre gece veya gündüz yapılmanın yanı sıra, bölgeye göre farklı aylarda da yapılmaktaydı. Anadolu ve Balkanlarda yaz aylarında yola çıkan kafileler, Bağdat ve Halep taraflarında sonbahar ve kış aylarını tercih ederlerdi (Orhonlu, 1984: 142). Özellikle yaz mevsiminde yeğlenen gece yolculuklarının temel sebebi tehlikeli bir durum olan havanın sıcaklığından ve güneş çarpmasından korunmak veya su ihtiyacını kontrol etmekti. Ayrıca gece yolculuğu gündüz sona ereceğinden, yemek pişirmek, çadırları uygun şekilde kurmak veya hayvanların tımarlarını yapmak gibi genel gereksinimler, gündüz gözüyle daha iyi yapılabilmekteydi (Tavernier, 2010: 145).

Ortalama altı ile on-on iki saat arası süren gece yolculukları, genellikle gece on bir veya gece yarısından sonra iki gibi başlamaktaydı. Daha önceki bir saatte yola çıkıldıysa bile sabahın ilk ışıklarında varılacak yere ulaşmak, sıcaklar çökmeden yerleşmek ve dinlenmek demekti. Yani gün doğumu ile geceleyin başlanan hareket arasında doğru orantı bulunmaktadır. Ancak bu durum kervanın güneş doğunca hemen konaklayacağı anlamına gelmemekteydi. Konaklama tamamen yakıcı güneş, kervandakilerin yorulma durumu veya ulaşılması planlanan menzile göre belirlenmekteydi. Gece belirtilen saatte yola çıkılmasının diğer bir sebebi ise ayın yükselmesi ile alakalıdır. Gündüzleri güneşten faydalanıldığı gibi geceleri de ayın ışığından faydalanmak zaruriydi. Nitekim 17. yüzyılın ilk çeyreğinde Halep'ten Antakya'ya giden Petri Della Valle bu durumu açıklayan şu ifadeyi kullanmaktadır: "gün içinde bir miktar yolu arkamızda bıraktıktan sonra, (akşam olunca) ayın yükselmesine kadar biraz dinlenerek yolumuza öyle devam ettik" (Valle, IV, 1674: 197).

Gece yolculuklarının da duruma göre zorlukları ve tehlikeleri bulunmaktaydı. Bunların başında eşkıya baskınları ve hırsızlık olayları gelirken; diğer bir husus, zorlu yollarda yapılan yolculukların gündüze göre daha meşakkatli ve tehlikeli olmasıydı. Bundan dolayı dar ve uçurumlu yollarda bilhassa gündüz yolculukları tercih edilmekteydi. Örneğin Troilo'nun katıldığı kervan, Torosların dar geçitlerle dolu ve uçurumlu yollarını gece yerine gündüz yürümeyi tercih etmişti (Troilo, 1676: 557).

Gece yolculuğunun diğer bir sıkıntısı ise uykusuzluk problemiydi. Tavernier kervan halkının bu problemle, tütün içerek, şarkı söyleyerek veya aralarında konuşarak baş etmeye çalıştıklarını belirtmektedir. Her şeye rağmen sabaha karşı dayanılmaz noktaya ulaşan uykusuzluk, insanların atlardan düşmelerine sebep olmaktaydı. Buna bir çözüm olarak mal sahipleri -güvenli bölgelerde- küçük gruplar halinde önden giderek kervan kavuşuncaya kadar 
birkaç saat uyuma firsatı bulmaktaydılar (Tavernier, 2010: 146). Tavernier uyuyanların attan düşmelerine sebep olan durumun diğer insanların uyuyanlara vurması olduğunu belirtmektedir. Kendisine kimse dokunmadığı için attan düşmeden uyuma firsatı bulduğunu belirten seyyahın bu durumu, diğer tacirlerle yakın ilişki kurmamasıyla açıklanabilir.

Gündüz yolculukları ise genellikle kış döneminde yapılmaktaydı. Çünkü k1ş döneminde geceleri hem kar yağışları fazla olmakta hem de yöreye göre buz ve don olaylarıyla daha fazla karşılaşılmaktaydı. Seyahatlerin çoğunlukla sıcak aylara gelecek şekilde tasarlanması gündüz yolculuklarının gece yolculuğuna göre oldukça az yapıldığı sonucunu çıkarmaktadır.

Hava şartlarının uygun olmaması, yolculukların gece veya gündüz yapılması fark etmeksizin, yollarda çekilen zahmeti katlamaktaydı. Kış aylarındaki kar, buz ve soğuk; bahar aylarındaki yağmur ve kuru soğuklar/rüzgâr; yaz aylarında ise güneş ve sıcak hava her mevsime göre yaşanan sıkıntıları özetlemektedir. Moncony'nin seyahat ettiği Nisan ve Mayıs aylarında yaptı̆̆ Antakya-İstanbul arasındaki yolculuk maruz kaldıkları yoğun yağmurlar dolayısıyla oldukça zor geçmişti (Monconys, 1697: 363-375). Kış yolculuğuna ise Makarius'un Sivas-Kangal arası yolculuk örnek verilebilir. Seyyah, Deliktaş ${ }^{13}$ taraflarında kar $^{14}$ ve soğuklar yüzünden büyük sıkıntılar çekmiş ve bu durumu şöyle aktarmıştır: “...ve yine soğuğun ve buzun ve rüzgârın çektirdiği acıyı açıklaması (tarifi) çok zor. Yüzümüz bir siyahi (zenci) kadar siyaha dönüştü. Delkeli Caya (Deliktaş) adını verdikleri dağın tepesine çıktığımızda aptallaştık ve şaşkina döndük ve gözlerimiz etrafi yoğun kardan dolayı dondu ve yol da kayboldu. Ama Tanrı bize merhametliydi de bizden önce gelen bir kurye bize yolu açtı." Karın yolları kapattı̆gı zamanlarda nereden gidileceğini kestirmenin zorluğu bilindiğinden yöre halkı söz konusu yolun her iki tarafina ağaç dikerek yolculara büyük bir kolaylık sağlamışlardı. Bu işaretler Makaryus'un bu yolun gördüğü en korkunç yol olduğu düşüncesini değiştirmemiştir. Öyle ki kendilerine bir yıl önce bu yolda bir kervanın tamamen kaybolduğu söylenmiştir (Aleppo, 1836: 447-448).

${ }^{13}$ Makaryus burası için "Delkeli Caya" ifadesini kullanmıştır. Fakat bu isimde bir yer olmamakla beraber bu ismi çağrıştıran tek yer Sivas'ın Kangal ilçesine bağl1 "Deliktaş" beldesidir.

${ }^{14}$ Karlar, geçmesi normal zamanlarda da zor olan yüksek veya tehlikeli geçitleri aşılması imkânsız yollara dönüştürmekteydi. Örneğin Tosya taraflarındaki Direklibel Geçidi her iki engelin aynı anda yaşandığ 1647-48 yılı kışında Defterzâde Mehmed Paşa'nın Erzurum dönüşünde önden özel teçhizatlarla (kar malzemeleri) yolladığı öncü adamları tarafından dahi aşılamamıştı. Buradan geçen ordu veya kişiler bu geçidin etrafında dolaşmak zorunda kalıyorlardı. Geniş bilgi için bk. (Taeschner, 2010: 241-248) 
Erzincan-Zara arasında "Kaplanlı Beli" adında bir yerden geçen Evliya Çelebi de soğuktan dolayı çektikleri sıkıntıları şu şekilde aktarmıştır: "Ne 'ûzubillah bir şiddet-i şitâ ve bir derf ü dipi ve boran çekerek cümle develerin ayaklarına keçe pareleri bağlayarak ve cümle bâr şütürleri katırlara yükledüb bir günde bu Kaplanlı Beli nâm belâyı gücile aşup ol gece kar üzre cümle askerlerle yatup dirahtı müntehâları ateşe urup orman kebâbı fasılları etdik." (Evliya Çelebi, V, 2011: 32). Develer farklı iklimlere dayanıklı olmasına karşın yaralandığı veya hasta olduğunda geç iyileşen bir hayvan olmasından dolayı (Önkal, Bozkurt, 1994: 226) ayaklarına keçe sarıldığı kanaati oluşmaktadır. Katırların dayanıklılı̆̆ının da anlaşıldığı bu ifadelerde Evliya'nın "ellerindeki bütün odunları da yaktıklarını belirtmesi" soğuğun boyutlarını ortaya koymaktadır.

Yolculuklarda rahatsız edici diğer bir husus, özellikle geceleri musallat olan sivrisineklerdi. Troilo yolculuk esnasında çalılarla büyük bir ateş yakan hizmetçilere neden böyle yaptıklarını sormuş onlar da sivrisineklerin bu şekilde kaçtıkları yanıtını vermişlerdi (Troilo, 1676: 484). Günümüzde köylerde de yapılan bu yöntem çoğu zaman işe yarayan bir uygulamadır. Çünkü sivrisinek ve diğer haşereler dumandan rahatsız olurlar. Ateş yakmak sineklerden korunmanın bir yöntemi olsa da, gece yakılacak büyük bir ateşin, etrafta olan hırsızları o bölgeye çekme ihtimali de vardı. Nitekim Troilo -tam da bu noktada- ateş yakan hizmetkârların niyetlerinin hırsızları çağırmak olabileceğini düşünerek endişesini dile getirmiş ve kısa süre sonra dediği gibi hırsızlar ateşi görerek yanlarına gelmişti. Bunun olacağını hesaplayan ve yolcuların silahlarını hazırladıklarını fark eden hırsızlar, sadece onların oradan uzaklaşmalarını istemişlerdi (Troilo, 1676: 484).

\section{Su ve Yemek}

Yoldaki en önemli tehlikelerden birisi de susuz kalmaktı. Tavernier yolların su yataklarına paralel uzandığını ancak su bulunmayan yerlerde, Türk misafirperverliğinin bir gereği olarak, sarnıçların yapıldığını yazmıştır. Yağmursuz geçen dönemlerde bu sarnıçlar civar köylüler tarafindan su ile doldurulmak suretiyle yolcuların su ihtiyacı karşılanmaktaydı (Tavernier, 2010: 126).

Yolculukların süresi -gün ve ay ışığı dengesi yanında- su kaynaklarının birbirine olan uzaklıklarına göre bazen altı saat, bazen de on-on iki saat sürebiliyordu (Tavernier, 2010: 145). Thévenot'un Halep-Musul seyahatinde seyyahın her menzilde bir su kaynağından bahsetmesi bu durumu açıklayan bir husustur (Thévenot, 1693: 57-70). Özellikle yaz döneminde ve Anadolu'nun güney kısmındaki yolculuklar için su kaynakları vazgeçilmez bir ihtiyaçtır. 
Suyun olduğu yere varıldığında ise yeni bir problemle karşılaşılıyordu. Aynı anda birkaç kişinin istifade edebileceği bir kaynağa gelindiğinde öncelikle yük hayvanlarının su ihtiyacının giderilmesine müsaade edilmekteydi. $\mathrm{Bu}$ konuyu seyahatte çekilen en büyük sorunlardan birisi olarak sayan Tavernier, zikredilen duruma Frenk kurnazlı̆̆ ile bir çözüm bulmuştur. Seyyah son seyahatinde yanında götürdügü küçük yeğenini, su kaynağına varıldığında su almaya yolladığını, suyun etrafındaki kervancıların çocuğu görünce acıyarak, ona su doldurması için öncelik tanıdıklarını, böylece her seferinde küçük yeğeni vasıtasıyla suyu önce temin etme noktasında bir sıkıntı yaşamadığını övgüyle anlatmaktadır (Tavernier, 2010: 149). Bu problemin hafife alınmamasi gereken bir durum olduğunun altını çizen Tavernier'in aktardığı rivayete göre; Bağdatİsfahan yolunda böyle bir su sırasında bir kölenin efendisinin emri üzerine kuyunun başına giderek 1srarla su istemesi üzerine çıkan arbede de, söz konusu köle oradaki bir kervancıyı öldürmüştür (Tavernier, 2010: 150-151).

Derin bir kuyuya rastlandığında suların kovalarla kuyudan çekilmesi gerekliliği ve kuyu suyu alındığında yerine yeni suyun zamanla dolması veya suyun çok derinde olmasından dolayı ancak öküzler vasıtasılyla çekilmesi de insanların ve hayvanların su ihtiyacının karşılanmasının epeyce zaman alması demekti (Troilo, 1676: 496).

Yolda su ihtiyacını karşılamak için herkesin deriden yapılma bir matarası bulunmaktaydı. $\mathrm{Bu}$ mataralar eyerin kaş kısmına veya arkasındaki mataralara özel yapılmış kancalara takılarak taşınmaktaydı (Tavernier, 2010: 148).

Yolculuğa çıkmadan önce ciddi bir hazırlık yapılmasına rağmen yollar uzadıkça vücudun ihtiyacı olan proteini depolamak için gerekli olan eti ve diğer yemekleri pişirmek için dağ başında gereken en önemli ihtiyaç yakacak malzemelerdir. Ormanlık arazilerde yüründüğünde veya kervansaraylarda sorun olmayan yakacak ihtiyacı, çorak arazilerde gidilirken hayli ciddi sorunlara sebep olmaktaydı. Tournefort Bayburt-Erzurum arasındaki yolcuğunda ellerindeki kuzuları pişirememenin, sadece paşanın yanında yedikleri reçellerle geçinmenin zorluklarını anlatmıştır (Tournefort, II, 2005: 128). Saatlerce gidilen yollarda yakacak hiçbir şeyin bulunmaması gerçek bir sıkıntı olsa gerektir. Ayrıca odun bulunsa bile azlığından dolayı pahalı olması da (yerleşim yerlerinde) ayrı bir ekonomik problemi ortaya çıkarmaktaydı. Ancak odunun tek başına yakacak olmadığı günümüzde doğu ve güneydoğudaki köylerde yaygın kullanılan tezeğin bazı yerlerde ulaşılabilecek tek yakacak kaynağı olduğu Tournefort'un notlarından anlaşılmaktadır ki kendisinin hiç hoşuna gitmemiştir. Zira ona göre tezekle pişirilen her şey is kokmaktadır (Tournefort, II, 2005: 129). Tournefort'un 
şikâyet ettiği tezek kokusunun bütün yolcular için aynı ölçüde problem olmadığı, yani bu durumun genelleme yapılmaması gerektiği göz ardı edilmemelidir.

\section{Eşkıya ve Hırsızların Yol Basmaları ve Yağmaları}

16. yüzyılda başlayan ve 17. yüzyılın sonuna kadar etkisi devam eden Celali isyanları, bu yüzyılın başında bütün Anadolu'yu kasıp kavuran bir süreci başlatmış ve "büyük kaçgun"15 olarak adlandırılan bu dönemde yollar hiç görülmediği kadar tehlike altına girmişti. Kentlerdeki ahalinin dahi kendini güvende hissetmediği isyanlar dönemi, yol güvenliğinin de kalmadığı bir dönem olmuştur. Naîmâ'nın Revan taraflarında bir kervana yapılan baskını anlatırken kurduğu şu cümleler olayın vahametini gözler önüne sermektedir: “ ... karbana rast gelip, aç kurt koyuna girer gibi girişip cümlesin karîn-i helâk ve demâr ve nehb-i emvâl-i bî-şumâr eyleyip halâ ba 'zl kurada ayş ü safâda ve câm-ı bâde ile mahmur yaturlar." (Naîmâ, I, 2007: 251). Anadolu'nun içlerinde Canbolatoğlu, Kara Haydar, Haydaroğlu ve bunları takiben de Katırcıŏglu gibi birbiri ardı sıra türeyen meşhur eşkıyaların yaptıkları zulümler yol emniyetini ortadan kaldıracak duruma getirmekteydi (Naîmâ, III, 2007: 1109,1114,1206). Eşkiyalar kervanları bastıklarında kervanın büyüklüğüne veya taşıdığı malın cinsine göre büyük vurgunlar yapmaktaydılar. Örneğin Deli Süleyman ve refiki Deli Mehmed adındaki eşkıyalar, Alacahan'da (Sivas/Kangal) bir kervana baskın düzenleyip $80.000^{16}$ kuruş nakit ve eşya vurgunu yapmışlardı. Ancak bu eşkıyalar çaldıkları bütün mallarla beraber yakalanıp esir edildi ve hepsinin boyunları vurulmuştur (Naîmâ, III, 2007: 1529).

Baskın yapan eşkıyaların yakalanarak cezalandırılmaları diğerlerini kervanlara saldırmaktan alıkoymadığı gibi, yolcuların da Anadolu'nun her bir tarafina yayılan isyan havasından kendilerini güvende hissetmeleri söz konusu değildi. Bu sebepten dolayı ancak bütün isyancı başlarının yakalanması gerekmekteydi. Kuyucu Murad Paşanın mücadelesi sonucunda büyük oranda etkisini kaybeden isyanlar ve eşkıyalık hareketleri, Sultan II. Osman'ın katledilmesine müteakip bir artış gösterse de Köprülü Mehmet Paşanın aldığ 1 önlemler neticesinde bitme noktasına gelmişti ${ }^{17}$. II. Viyana Kuşatması ile birlikte 17. yüzyılın sonuna kadar devletin dış güçlere karşı verdiği büyük savaşlar sebebiyle Anadolu'nun korumasız kalması bölgedeki isyan ve eşkıyalıkları

15 Celali eşkıyalarının yaptıkları amansız soygun ve katiller sebebiyle Anadolu köylüsünün toprağından kaçması olayına denmektedir (İnalcık, I, 2012: 194)

16 17. yüzyılın başlarında 1 kuruş 8o ayarı tam kuruşa tekabül etmekteydi ki (Pamuk, 2002: 458) bu da toplamda altı milyon dört yüz bin akçe yapıyordu.

${ }^{17}$ Mehmet Paşa Anadolu'da büyük bir teftiş başlatmış ve 80.000 civarı silah toplayarak isyanların önüne geçmiştir (İnalcık, III, 2015: 57). 
artırmıştı (Orhonlu, 1963: 7-8). Orhonlu bu dönemde Saruca-sekbanların sayılarının binleri bulabildiğini belirtmektedir. Öyle ki kalabalık gruplar halinde dolaşarak hem köy ve kasabalara salgunlar salıyor hem de yerleşim birimleri arasındaki yol ve seyahat emniyetini yok ediyorlardı (Orhonlu, 1963: 39-40). Neticede eşkıyalık faaliyetleri neredeyse bütün Anadolu yollarına yayılmaktaydı. Nitekim merkezde yollanan bir fermanda Anadolu'nun sağ kol, orta kol ve sol koldaki kadı, eyalet mütesellimi, kethüdayeri, yeniçeri serdarları ve ayanlardan yol kesip adam öldüren kapısız levendler ile Türkmen ve Kürd eşkıyaların hakkından gelinmesi emredilmiştir (BOA. A.DVNSMHM.d., 98, 136).

Kervandakilerin sayıca az olması eşkıyalar için kolay baskınlar yapabilecekleri anlamına gelmekteydi. $\mathrm{Bu}$ bakımdan çok kalabalık olan kervanlara katılmak, çoğunlukla ıssız olan yörelerde kalabalık çeteler halinde dolaşan eşkıyalardan korunmak amacını da taşımaktaydı. Bazı kervanlar o kadar kalabalıktı ki 600 deve ve bir o kadar da atlı beraber yol almaktaydı (Tavernier, 2010: 145). Bu sayı çok gibi gözükse de aslında orta ölçekte bir kervan olarak kabul edilmektedir. Çünkü büyük bir kervanda 2500 kadar deve bulunabilirdi (Orhonlu, 1984: 141-142). Tournefort "sefil" olarak bahsettiği hırsızların özellikle yalnız gezginleri soyduklarını, kervanlara kalabalık olmalarından dolayı ilişmediklerini vurgulamışıı. Ancak Tournefort'a göre hırsız veya eşkıyalardan korunmanın püf noktası kalabalık kervanları beklemek yerine kendini iyi savunan kişilerin çok olduğu kervanları tercih etmekti (Tournefort, II, 2005: 122).

Kervanların kalabalık olması bazen düzensizliği veya kontrolsüzlüğü de beraberinde getirebiliyordu. Örneğin Moncony Eskişehir civarında kendi kervanlarının da dahil olduğu surre alayının soyulduğu bilgisini vermektedir. Seyyah oldukça kalabalık olduğunu belirttiği bu kervanı takip eden 21 atlı hırsızın dört at ile birlikte sekiz tane yüklü eşeği kaçırdıklarını kaydetmiştir (Monconys, 1697: 373). Surre kervanları Anadolu içlerinden ziyade Suriye taraflarında daha çok saldırıya uğramaktaydı. Nitekim 17. yüzyılın sonlarına doğru Arap çeteleri eşkıyalık faaliyetlerini hac yolu da olan Suriye taraflarında yoğunlaştırınca surre kervanlarının güvenlikleri de artırılmıştır (Jorga, 2017: 354355). Hac kervanı söz konusu bölgelerdeki tehlikelere karşı Kanuni döneminde 150 yeniçeri ve 100 sipahiden oluşan askeri birlikler tarafından korunmaktaydı. Yeniçerilerin dışında Suriye ve Mısır'da hac kervanlarının güvenliği ve diğer hizmetler için bedevilere de yüklü ödemeler yapılmaktaydı (Faroqhi, 1995: 6276). ${ }^{18}$

${ }^{18}$ Faroqhi 17. yüzyılın başında bedevilere ödenen paranın 15000-17000 altın arasında hatırı sayılır bir ödeme yapıldığını tespit etmiştir. Surre alayı ve hac kervanlarının Suriye ve Mısır

[2098] 
Kervanlar kalabalık olunca tüccar ve yolcuları gidilecek yere vaktinde ve sağ salim ulaştırmak için iyi bir organizasyon gerekmekteydi. Bu bağlamda söz konusu eşkıyalarla karşılaşmamak veya onları bertaraf etmek için tecrübeli tüccarlar arasından kervanbaşı seçiliyordu. Büyük bir sorumluluk alan bu kişiler kervanı gideceği yere kadar güvenli bir şekilde götürmekle yükümlüydüler. Tavernier kervanbaşının kervanın maiyetinin çoğunluğuna göre belirlendiğini kaydetmektedir. Yani kervanın çoğunluğu Türklerden oluşuyorsa kervanbaşı da Türkler arasından seçiliyordu (Tavernier, 2010: 144). Kervanbaşl1ı zor bir görev olmakla birlikte görevi yerine getiren kişiye deve başına belli bir ücret ödendiği için -kervanın büyüklüğüyle orantılı olarak- iyi bir gelir kapısıydı (Orhonlu, 1984: 144). Ordunun sefere gittiği zamanlarda da yolun kontrolü, güvenli olup olmadığ 1 ve doğru güzergâhın takip edilmesi noktasında devletin yol üzerindeki kazalardan belli sayıda klavuz temin ettikleri görülmekteydi (Kocaoğlu, 2020: 48-53). Neticede yol güvenliği tek kişiden binlerce kişiye kadar herkesin bölgeyi tanıyan kişilerin rehberliğinde gitmeleri güvenlik açısından elzem bir durumdu.

Yol rehberlerine sadece güvenlik açısından ihtiyaç duyulmamaktaydı. Misalen 1700'lerin başında Bitlis ve Palu beylerine gönderilen bir emirde, bölgeden geçen tüccarların yanlarına güvenilir adamlar verilerek Erzurum gümrügüne ulaştırılmaları istenmiştir. Gerekçe ise eskiden beri bu bölgeden geçen kervanı kendi bölgelerinden geçirmek isteyen beylerin kervan yolunu değiştirmeleri sonucu tacirlerin bunaltıcı yollardan gitmek zorunda kalmalarıydı. İşte bu noktada padişahın tacirleri sıcaktan bunaltmayacak yollardan götürmeleri için yanlarında güvenilir adamlar verilmesini emrettiği görülmektedir (BOA. AE.SAMD.III, 18, 1718).

Soyguncular genellikle yaz dönemlerinde hırsızlık yapıyorlardı. Önceden de belirtildiği gibi bunun bir sebebi kervanların daha çok yaz döneminde yolculuk yapmaları, diğeri ise kış döneminde hem dağ şartlarının zorluğu hem de hayvanlar için yem bulma sıkıntısıydı. Bu sebeple haziran, temmuz ve ağustos ayları hırsız ve eşkıyalar için en ideal aylardı (Tournefort, II, 2005: 139).

Kervanların geçtiği bazı bölgeler tehlikeli olmalarıyla ün salmış, hatta bu bölgelerin isimlendirmeleri de buna uygun olarak verilmişti. Örneğin İzmirAfyonkarahisar arasında Eşme yakınlarında olduğu tahmin edilen bölgeye "Hırsızlar Dağı" adı verilmişti (Tavernier, 2010: 124). Kervancılar böyle yerlerin yakınlarında bulunan kervansaraylarda dahi dinlenmeyi tercih etmeyerek, daha fazla yol alıp başka bir kervansarayda mola vermeyi uygun görmekteydiler. Mesela, Thévenot'un dâhil olduğu kervan kafilesi İzmir civarındaki hırsızların

taraflarında nasıl korundukları ile ilgili Faroqhi'nin kaleme aldığ 1 "Hacılar ve Sultanlar" adlı eserde geniş malumat verilmektedir (Faroqhi, 1995: 58-81).

[2099] 
çok olduğu Gelembe kasabasında durmayarak daha ilerideki bir kervansarayda durmayı tercih etmişti. Seyyah buradaki hırsızların kimler olabileceği konusunda da bazı yorumlar yapmıştır. Ona göre söz konusu şakîler ${ }^{19}$, Çanakkale savaşlarından ${ }^{20}$ kaçan Berberilerdi ${ }^{21}$ (Thévenot, 2009: 117). Thévenot bu civarda bulunan eşkıyanın özellikle Hristiyanları hedef aldığını vurgulamıştır. Bu iddiaya temkinli yaklaşmak iktiza etmektedir. Zira eşkıya veya hırsızların, hedef aldıkları kervan ahalisinin etnik oranını önceden bilmesi pek mümkün olmasa gerektir. Diğer taraftan Thévenot'un iddiası doğru kabul edilse bile, bu durum ancak dönemsel olarak değerlendirilmeli genel bir yargıya varılmamalıdır. Yani buradaki yol kesen zevat eğer söz konusu Çanakkale ablukasından kaçanlar -onun ifadesiyle "kılıç artıkları"- ise Venediklilerin de Hristiyan olmaları sebebiyle Hristiyan yolculara bir düşmanlık beslemiş olabilirler. Çünkü savaş tam da seyyahın gittiği yıl (1656) yapılmıştır. Benzer bir hadise Köprülü Mehmed Paşanın sadareti döneminde Balıkesir' in Susurluk bölgesinde ortaya çıkmıştı. Bu bölgede yüz yirmi civarı "yolkesen ve haramzadenin" Sarı Ali namında bir eşkıya başıyla kervanlara saldırdıkları haberi İstanbul'a ulaşınca, Saruhan sancağı Mutasarrıfına vakit geçirmeden şakilerin haklarından gelinmesi bildirilmişti (Ulusoy, 1944: 82).

Thévenot'un eserinde geçen şakilerin bahse konu olan savaştan kaçan kişiler olup olmadığı daha fazla bilgi ve belgeyle kesinleştirilebilecek bir iddia olsa da bu dönemde Anadolu'da eşkıyalık faaliyetlerine girişenlerin önemli bir kısmının levendlerden veya levend olarak adlandırılan güruhtan oluşmaktaydı. Y1lın belli dönemlerinde denizde veya tersanelerde görevlendirilmek üzere Anadolu'dan toplanan levendlerin bir kısımı görev süreleri bitince beylerbeyi, sancakbeyi gibi yerel idarecilerin kap1 halk1 olarak veya devlet tarafindan kalelerde azap ve yeniçeri olarak görevlendirilmekteydi (Kütükoğlu, 2018: 85). Bazıları ise işten çıkartılarak kendi hallerine bırakılan ve dönemin kaynaklarında "kapısız levend" veya "bacasız levend" şeklinde adlandırılan işsizler ordusuna ve nihayetinde başıboş eşkıyalara dönüşmekteydi (İlgürel, 2003: 149-151). Cezar’a

${ }^{19}$ Eşkıya, yol kesici, haydut manalarında kullanılmaktadır.

20 Seyyahın bahsettiği hadise, Sultan IV. Mehmed'in saltanatının daha ilk yıllarından itibaren Venediklilerle Çanakkale boğazı ve Bozcaada, Limni gibi adalar etrafında cereyan eden savaşlardır. Venedik donanması yaklaşık sekiz yıl boyunca Çanakkale boğazını ablukaya almış ve Payitahttaki esnafi ciddi anlamda ekonomik sıkıntıya sokmuştu. Söz konusu abluka ancak Köprülü Mehmed Paşa tarafından kaldırılarak boğaz yakınlarındaki adalar da kurtarılabilmişti.

${ }^{21}$ Kanaatimize göre, Thévenot'un "Berberiler"den kastı Kuzey Afrika'da yaşayan halktan ziyade, Batı dünyasının kendilerinden olmayan halklar için kullandıkları ve acımasız, cani vb. anlamlar yükledikleri "Barbar" tanımlamasıdır. Ayrıca "Berberi" kelimesi de "barbar" kelimesinin Araplar tarafindan farklı bir telaffuzundan ibaret (Yıldız, 1992: 478-479) olduğu için yine barbarlık kast edilmiş olmalıdır. 
göre levendlerin devamlı eşkıyalar haline gelmeleri Kanûni'nin oğlu Şehzade Bayezid zamanından sonra başlamıştır. Celali eşkıyalığının genişlemesinde de zamanla çoğalan bu levendlerin büyük etkisi olmuştur. Bu bağlamda yollarda yağma yapan levendlerin sadece sefer bitince ortaya çıkan çeteler olmadığ 1 , bilakis zaman içinde (çift bozan durumuna düşenleri de etraflarında toplayarak) irili ufaklı celali eşkıyalarının da bunlar arasından çıktığı anlaşılmaktadır (Cezar, 1965: 191-195). Akdağ zaman içinde "çiftbozan" adını alanlara "suhtevât"1 da eklemektedir. 16. yüzyılın ortalarında sayıları her zamankinden fazla olan orta seviyedeki medrese öğrencilerinin (suhte) çoğu icazet almakla beraber yüksek medreselere giremeyince bilhassa Anadolu'da halkın başına bela olmaya başladılar (Akdağ, 1995: s. 69-71).

Eşkıyalık faaliyetlerinin muayyen dönemler hariç Anadolu'nun belli başlı yerlerinde yoğunlaştı̆̆ düşünülmektedir. Bunlardan birisi olan Tokat ve civarı eşkıyalara sık rastlanan noktalardandı. Tournefort'a göre birçok saldırı olayının Tokat taraflarında meydana gelmesinin nedeni, burasının ticaret kervanlarının buluştuğu önemli bir kavşak olmasıydı. Zira önceden de değinildiği gibi, İzmir'den, İstanbul'dan, Bursa'dan, Samsun'dan, Erzurum'dan veya Diyarbekir'den gelen ve değerli mallar taşıyan kervanlar bölgeye daha fazla eşkıya, haydut veya hırsızların toplanmasını sağlamaktaydı.

İran'dan gelen kervanların toplanma yeri olan Tokat yakınlarındaki Takıbak mevkiine gelen Tavernier, yanında oldukça değerli İran yünleriyle beraber çok kıymetli misk kokuları taşıdığından olsa gerek hırsızların dikkatini çekmişti. Hırsızlık olaylarına karşı ihtiyatlı davranan seyyah yüksek pahadaki misklerini iki sıra halinde yerleştirmiş ve birbirine bağladığı yün balyalarının çadıra yakın olan tarafında başına değecek kadar yakınında tutmak suretiyle değerli mallarını emniyete almıştı. Ancak miskin yoğun kokusu ve yanlarında muhafız olmaması hırsızların gecenin karanlığından istifade ederek seyyahın önlemlerine rağmen dıştan iki balyasını çalmalarına sebep olmuştu. Tavernier hırsızların konaklanan yerdeki mal çalma yöntemini, "geceleri gelen hırsızlar sürünerek çadıra yaklaşmakta ve sessizce balyaların iplerini kesmekteydiler" şeklinde izah etmektedir (Tavernier, 2010: 131-132). Hırsızların kullandıkları diğer bir yöntem ise eşyaları sessizce çadıra yaklaşarak çengel ile çekme yöntemiydi (Tournefort, II, 2005: 134).

Tokat taraflarında eşkıyalarla (seyahatnamede haydut olarak kaydedilmiştir) karşılaşan diğer bir seyyah Tournefort'tur. Yirmi dört deveden oluşan bir kervanla hareket ettikleri için önlerinde haydutların olduğu haberi kervandakileri hayli korkuttuğunu belirten seyyah bu hadiseyi şu cümlelerle aktarmaktadır: 
"Tokat yolunda birçok haydut olduğunu ögrrendik, bu yüzden ırmă̆ iki kez aşmak zorunda kaldık. Haydutların gelmekte olduğu haberi üzerine toplandık, direnebildiğimiz kadar direnmeye karar verdik. Yürüyüşsirasında ipek yüklü atları ortamıza almaktan da geri kalmadık ve kimi zaman atlar, kimi zaman artçılar arasında yürüdük. Saat on bire doğru daha da dar bir vadinin girişine ulaştık. Tepenin sırtlarında bu tehlikeli yeri görebileceğimiz bir yere ulaşınca, geçidin durumunu görmek üzere üç tüfekçi gönderdik; ne mutlu ki, yalnizca dağda yürüyen üç dört silahlı adam gördükleri haberini getirdiler; böylece geçidi tek sözcük etmeden ve elden geldiğince acele ederek geçtik... Bir gün sonra (eylül ayl), bizimki kadar güçlü bir ipek kervanina katıldık. Bu kervan bizden iki gün sonra Erzurum'dan yola çıkmış ama azledilmiş bir paşanın haydutların başına geçtiği söylentisi üzerine daha hızl yol almıştı." (Tournefort, II, 2005: 217)

Tournefort'un bu anlatımı haydutlara/eşkıyalara karşı nasıl davranılması gerektiği konusunda bir fikir vermektedir. Ancak kervanlar için daha büyük tehlike, başında güçlü bir isyancının olduğu eşkıyalık hareketleriydi. Tournefort'un bulunduğu kervan yolunun devamında yirmiye yakın eşkıyayla karşılaşılmasına rağmen, eşkıyalar tam donanımlı olan bu kervana saldırmaya cesaret edemeyerek çekilmişlerdi (Tournefort, II, 2005: 218). Çünkü düzensiz veya daha az sayıdaki eşkıyalar ancak kendilerini daha üstün gördüklerinde bir kervana saldırabilmekteydiler.

Anadolu'nun doğusunda başlayan, Erzurum ve Sivas gibi merkezlerde oturan paşaların başlattıkları isyan hareketleri (Abaza Mehmet ve Hasan Paşalar, Varvar Ali Paşa, İpşir Paşa gibi) 17. yüzyılda devletin önemli sorunları arasında görülmektedir. Abaza Hasan isyanı için Sultan IV. Mehmed'in; "Kullarım, Abaza Hasan dedikleri mel'ûn ... bir alay eşkıyayı başına cem ' edip Anadolu memâlikini yağma vî gâret ile fesâda verdi" (Naîmâ, IV, 2007: 1805) şeklindeki hitab1, isyanın Anadolu'daki durumunu anlatmaktadır. Öyle ki bu isyanlar yüzünden seyyahlar yollarını değiştirmek zorunda kalmaktaydılar. Örneğin Abaza Hasan Paşa isyanı çıktığı dönemde gemi yolculuğu ile Sinop'a gelen ve oradan Anadolu'nun güneyine inmeye çalışan Antakya Piskoposu Makaryus, zikredilen isyan dolayısıyla Sinop'tan Tokat'a kadar ana yolları değil, dağlar ve tepeler üzerinden geçen çamurlu patika yolları kullanmıştı (Aleppo, 1836: 437).

Gerek genel bir isyan grubu gerekse kalabalık eşkıya gruplarının saldırıları kervanın aldığı önlemlere ve önceden değinildiği gibi sayıca fazla olmalarına bağlıydı. Nitekim Troilo'nun dahil olduğu kervanın çok kalabalık olması ve iyi organize olunması onları Torosların güney eteklerinde bekleyen 300 kadar atlının 
(sayı mübalağalı olabilir) saldırısından korumuştur (Troilo, 1676: 557-558). Thévenot da Urfa'dan batıya doğru hareket etmeden önce 1000 kadar Arap atlının görüldüğü haberi alınınca yola çıkması birkaç gün geciken kervancıların silahlar ve mızraklarla hazırlık yaptıklarını, ancak bir sorun yaşanmadığını kaydetmiştir (Thévenot, 1693: 64). Her iki husus da eşkıya veya hırsızların oldukça kalabalık gruplar halinde dolaştıklarını, kervanlara saldırmadıkları durumlarda bile kervanlar üzerinde büyük tesirler yapacak kadar etkili olduklarını göstermektedir. Bazen de saldırılar acımasız sonuçlar doğurmaktaydı. Örneğin Türkmenlerin yoğun yaşadığı bir bölge olan Antakya taraflarında 300 kadar Türkmen, bir kervanı basarak hem yağma hem de katliam yapmışlardı (BOA. A.DVNSMHM.d., 102, 424).

Bütün kervanın tehlikelere karşı uyanık olması kadar yolcuların kervanın neresinde bulundukları da tehlikeyle karşılaşmada önemli bir faktördü. Tavernier bu hususta kervanın arkasında kalmamanın önemli olduğunu vurgulamıştır (Tavernier, 2010: 147). Kervanlara saldıran eşkıya ve haydutların nereden geldiklerine dair açıklayıcı bir kaydın olmaması dışında saldırıların zaman, yer ve niceliğe göre farklılık arz etmesi durumu, bu tedbirin her zaman işe yarayıp yaramadığ 1 konusunda soru işaretleri bırakmaktadır. Ancak "sürüden ayrılanı kurt kapar" sözüyle uyumlu olarak, kervana yetişemeyen veya en arkada kalan kişiler korumasız olacaklarından eşkıyalar için kolay lokma olabilirlerdi.

Eşkıyalara karşı alınacak önlemlerden birisi de çadırların konumuydu. Önceki kısımda değinildiği gibi, eşyalar sağlam bir şekilde çadırların çevresine veya kıymetine göre iç kısma alınmak suretiyle birbirlerine ve çadırlara bağlanarak yerleştirilmek zorundaydı. Ayrıca Tavernier'in belirttiğine göre yağmurlu havalarda çadırın etrafına kazılacak çukurlar hem yağmur suyunun çadırın içine girmesini önlemekte hem de hırsızlar için bir engel teşkil etmekteydi (Tavernier, 2010: 148). Eğer hırsızlar bütün önlemlere rağmen eşyaları çaldılarsa, onlarla anlaşıp istedikleri parayı vererek hem eşyaları hem de canını kurtarmak en iyi çözüm olarak görülmekteydi (Tournefort, II, 2005: 135).

Yolculuk esnasında karşılaşılan yolcu görünümlü kişilerin de hırsız olabilme ihtimali söz konusuydu. Troilo'nun İskenderun-Adana arasındaki yolculuğunda "tekin olmayan Türkler", yolculuk esnasında birkaç defa karşılarına çıkmış hatta onlarla beraber yol almışlardı. Kendisi ve yanındaki ağa bu kişilere güvenmediklerinden sürekli teyakkuzda olma gereği duymuşlar, silahlarını ateşe hazır duruma getirerek onları da başlarından savmanın yollarını aramışlardı (Troilo, 1676: 485-486). Seyyahın böyle bir durumla karşılaşmasının sebebi büyük bir kervanla yolculuk yapmamasının bir sonucudur. Nitekim Troilo bir kervansaraya vardığında çok rahatladıklarını ancak bu kişilerin de bir süre 
sonra kervansaraya geldiklerini aktarmıştır. Bunun üzerinde daha da tedirgin olan seyyah ve beraberindekiler kervansaray görevlisine yakınlarda Adana'ya giden bir kervanın olup olmadığını sormuş, bir kervan kafilesi bulamasalar da bütün tedirginliklerine rağmen Adana'ya sağ salim ulaşmışlardı (Troilo, 1676: 487490). Seyyahın bu yolcukta yaşadıklarının bir kısmı hayal ürünü gibi durmaktadır. Neticede Adana'ya sağ salim varmaları, herhangi bir soygunla karşılaşmamaları, kimseye zarar gelmemesi gibi durumlar anlatılanların gerçeklikten uzak olabileceği sonucunu doğurmaktadır.

Tournefort Tokat'tan batıya doğru gidilmeye başlanınca eşkıyalık faaliyetlerinin Kürtlerden Türkmenlere geçtiğini kaydetmiştir. Ona göre Türkmenler daha kötüdür. Çünkü Kürtler sadece gündüz soygun yaparken Türkmenler gece gündüz yapmaktadır. Ancak seyyahın bu yaklaşımı tartışmalıdır. Zira Tokat'tan Bursa'ya kadar herhangi bir haydutluk faaliyetinden bahsetmemiştir (Tournefort, II, 2005: 225). Söz konusu soygunculuk faaliyetleri 1rki bir temele oturtulamayacağı gibi batıya doğru daha az soygunun olması gidilen yolun devlet merkezine yakınlığı ile açıklanabilir. Ancak bu durum Türkmenlerin bir şey yapmadıkları anlamına da gelmez. Zira La Motraye'den alıntı yapan Jorga, Türkmenlerin aşırılıklarını şu ifadeyle açıklamaya çalışmıştır: "Anadolu'da herhangi bir asi ayaklanmadığı sürece, düşman doğudaki ele avuca siğmaz Türkmenlerdi" (Jorga, 2017: 357). Orhonlu 17. yüzyılın sonunda görülen Türkmen yağmalarını yaylak ve kışlak arasında gidip gelen konar-göçerler olduğunu ve saruca-sekbanlarla bir olup şehirleri dahi yağmaladıklarını vurgulamaktadır (Orhonlu, 1963, s. 40-41). Sivas taraflarında kervanı basan grubun Rakka iskânından firar edip gelen Cerid Türkmenleri olduğu dönemin kayıtlarına yansımıştır (BOA. A.DVNSMHM.d., 112, 81). Akdağ'ın ileri sürdüğ̈̈; Osmanlı'nın kuruluşundan Yavuz Sultan Selim devrinin sonuna kadar Anadolu'da görülen refah ve Rumeli fütuhatının bir sonucu olarak Balkanlara yerleşen halkın Anadolu'da sıkışması tezi bu durumu doğuran önemli bir etken olmalıdır (Akdağ, 1995: 97-98). Türkmen halkın bu faaliyetlerde daha Türkmenlerin Anadolu'ya geldiklerinden beri bu yağma faaliyetine girişmeleri bir bakıma göçebe yaşamla yerleşik yaşamın mücadelesinin sonucudur. Söz konusu mücadele 17. yüzyıldan çok daha öncesinde başlamıştı. Nitekim Anadolu Selçukluları döneminde de Anadolu'nun şarki vilayetlerinde yağma hareketlerine girişerek ve kervanları basarak geçimlerini sağlıyorlardı (Turan, 2017: 440-441).

Eşkıyalık veya soygun faaliyetlerinin bölgelere göre azalıp artmasında bölgesel faktörler önem arz etmektedir. Bunlardan bazıları (yüzey şekilleri, dönemsel olaylar, gece-gündüz fark1...) önceki kısımlarda sayıldığından tekrar etmeye lüzum yoktur. Diğer bir durum ise idari otoritenin aldığı tedbirlerdir. Örneğin Thévenot Diyarbekir'den geçtikleri esnada kalabalık ve silahlı bir 
Türkmen grubuyla karşılaştıklarını ancak onların yanlarından geçerek uzaklaştıklarını yazmıştır. Seyyah söz konusu kişilerin kervana saldırmamalarının sebebini Diyarbekir Beyi Dilaver Paşa'nın ${ }^{22}$ bu bölgedeki eşkıyaların haklarından gelmesine yormuştur (Thévenot, 1693: 65). 17. yüzyılın başlarında (Thévenot'tan önce) bu bölgede kervanlarla birlikte askerlerin de eşkıyalar tarafindan soyulduğu arşiv kayıtlarına da yansıyan bir husustur (BOA. A.DVNSMHM.d., 79, Hk. 920; BOA. A.DVNSMHM.d., 79, Hk. 1099).

Görüldüğü üzere kervanlara yapılan saldırılar farklı şekillerde meydana gelebilmekteydi. $\mathrm{Bu}$ saldırılar sonucunda ölen tacirlerin akıbetleri konusu Tournefort'un yaşadığı bir olaydan yola çıkılarak yorumlanabilir. Seyyah Tokat civarında birçok derme çatma taşlardan yapılmış mezar görünce, kim olduklarını sormuş, ona; eskiden daha tehlikeli olan bu bölgede eşkıyalar tarafindan öldürülen tüccarların olduğu cevabı verilmişti (Tournefort, II, 2005: 221). Bu örneğin gerçek olup olmadığı bir yana tek bir örnek olması da söz konusu durumu genelleyemeyeceğimiz anlamına gelmektedir. Ayrıca eşkıyanın saldırı sonrasında orayı terk edeceği, kervanın tekrardan toplanarak ölü ve yaralıları taşıyacağ 1 veya olay duyulduktan sonra çevreden gelecek kişi ve görevlilerin de bu hususta yardım ederek saldırıya uğrayanları canlı cansız göndermeleri daha olasıdır. Tournefort'un verdiği bilgi ancak yakını olmayan veya kim olduğu bilinmeyen kişiler için doğru bir örnek olabilir.

Eşkıyalar veya adi hırsızlık olayları dışında yaşanan ilginç bir durum Polonyalı Simeon'un başına gelmiştir. Simeon İzmir'e geldiğinde çok hasta olup bir yerde kalırken Beytülmal Emini $^{23}$ ölmek üzere olduğunu düşündüğü Simeon'un mallarını toplayıp götürmüş, seyyah da zor bela mallarını geri almıştı (Simeon, 2016: 121). Bu olay bir yol güvenliği meselesi olmasa da yolcularda karşılaşılabilecek bir örnek teşkil etmektedir. Bu bağlamda yolculuk sırasında ölen tacirler böyle bir uygulamaya tabi tutulmakta ve eğer yanlarında yol arkadaşları varsa geriye kalan malları onlara verilmekte veya geldiği ülke ile ilgili antlaşmalar uyarınca ülkesinin konsolosuyla irtibata geçilmekteydi (Bilgin \& Bozkurt, 2010: 13-14).

${ }^{22}$ Dilaver Paşa 1616 ve 1618 yıllarında Diyarbekir Beylerbeyi olarak görev yapmıştı. Paşa görevde bulunduğu dönemde Diyarbekir taraflarındaki isyan hareketlerini de bastırmıştı (Aykut, 1994: 297).

${ }^{23}$ Osmanlı'da miras bırakmadan ölen kişilerin malları sahipsiz mal addedildiği için Beytü'lmal emini tarafından kabzedilirdi. Simeon'un varisinin olmadığı ve ölmek üzere olduğu düşüncesi eminin böyle bir harekete girişmesine sebep olmuştur. Ancak bu örnek durumun suiistimale açık olduğunun da bir göstergesidir. Söz konusu görevlilerin haksız kazanç elde ettikleri ve türlü suiistimallerde bulundukları dönemin belgelerine yansımıştır. Geniş bilgi için bk. (Bilgin \& Bozkurt, 2010: 1-17) 


\section{Sarp Yollar}

17. yüzyılda yapılan yolculuklarda kullanılan yollardaki sarp geçitler, dağların üstünden aşan dar yollar, dönemin yolculuğundaki fiziki güvenlik sorunları olarak öne çıkmaktaydı. Öncelikle hayvanların çektiği arabalı seferlerin yapılamaması yolculuğun meşakkatini artırmaktaydı. Sarp yollardaki önemli tehlikelerden birisi üstünde ağır yükler taşıyan hayvanların bir tarafı uçurum veya kayalık olan yollardaki düşme tehlikesiydi. Özellikle Anadolu'nun yükseltisi fazla olan kuzey ve güney sıradağlarının aşıldığ 1 yerlerde ve yükseltiyle birlikte engebeli yapıdaki doğu yollarında söz konusu tehlike daha fazlaydı. Buna bir örnek olarak Tavernier' in Diyarbekir'den Bitlis'e giden yolda sarp bir araziden geçtiğini belirtmesi verilebilir. Burası için Tavernier'in yaptığ 1 şu tasvir önem arz etmektedir: "Halep'ten Bitlis'e giderken kente yaklaşıldığında tam bir gün boyunca sarp ve yüksek dağlarda yürünüyor ve bu dağlar kentin iki mil ilerisine kadar devam ediyor. Yolun her iki yanında ya sel yataklarl ya da dağ var; yol kayaların içine oyulduğu için, birçok yerde deve ya da katır suya düşmemek için ayağını çok dikkatli basmak zorunda." (Tavernier, 2010: 289) Söz konusu bu yol günümüzde dahi (Baykan-Bitlis arası / Bitlis Deresi mevkii) tehlikeli virajların olduğu taşıt yollarına sahiptir.

Sivas-Malatya arasındaki yol da Diyarbekir-Bitlis güzergâhı gibi sarp ve problemlidir. Makaryus söz konusu yolun sadece bir yük hayvanın geçeceği kadar dar ve bir yanının uçurum olmasından dolayı hayvanların ayaklarının birisinin yolun dışında kaldığı vurgulanmaktadır. Bu duruma bir de hayvanların içinde kaybolacağı kadar kar eklenince yolların çekilmez olduğu anlaşılmaktadır (Aleppo, 1836: 447). Bu örneklerden Anadolu'nun her tarafının problemli yollardan oluştuğu anlaşılmamalıdır. Çünkü başta Orta Anadolu olmak üzere yükseltisi az olan yerlerde veya yüksek ve düz platolarda rahat yolculuklar yapılmakta, hatta arabalarla gidilebilecek geniş yollar mevcuttu.

Kervancılar zorlu yollarda hayvanların daha az zarar görmesini sağlayan tedbirler almaktaydılar. Tavernier bu konuda oldukça teferruatlı tasvirler ve açıklamalar yapmıştır. Öncelikle develer tek sıra halinde yedişerli bir düzen içinde yürümekteydi. Bu düzen içinde yürüyen her bir deve katarı birbirlerine dayanıklı olmayan birer kulaçlık iplerle bağlanıyordu. Bu ipin bir ucu öndeki devenin semerinin arkasına bir ucu da arkadaki devenin burnunda takılı olan halkaya düğümleniyordu. Böylece eğer develerden birisi uçurumdan yuvarlanacak olursa ip kopar düşen deveye bağlı olan diğer develer uçurumdan düşmemekteydi (Tavernier, 2010: 145).

İple sağlanan güvenlik uygulaması haricinde bir de çıngırak takma uygulaması vardı ki kervancının çektiği develerin hepsinin onu takip edip 
etmediğini anlaması için kullanılıyordu. Kendi katarını çeken deveci, birbirlerine iple bağlı olan develerin sonuncusuna bir çıngırak takıyordu. Eğer çıngırağın sesi kesildiyse arkadaki bir devenin hareket etmediği, dolayısıyla bağlı olan ipin herhangi bir sebepten kopmuş olduğu anlaşılmaktaydı. Buradaki durum sadece basit bir ip kopması veya uçurumdan düşme hadisesi olmayabiliyordu. Çünkü Tavernier gece karanlığında hırsızların gizlice develere yanaşarak ipini kestiğini ve aradan devenin birini alıp gittiğinin fark edilebildiğini not etmiştir. Hırsızlığın bu kadar kolay yapılabilmesinin bir sebebi gece yürüyüşü, diğer bir sebebi de deve toynaklarında nal olmadığı için ses çıkmamasıdır (Tavernier, 2010: 146). Böyle bir hırsızlık olayı Moncony'nin kervanın başına gelmiştir. Baja adında bir köyün yakınlarında ${ }^{24}$ dağlık bir alanda meydana gelen hadisede; hırsılar mağaraların çok olduğu kuytu yerlere gizlenmek suretiyle tafta kumaşlarıyla yüklü bir deveyi yüküyle beraber sessizce kaçırmışlardı (Monconys, 1697: 372).

Basit ama uyulmaması durumunda bazı sıkıntılara sebep olan diğer bir hareket ise atların başlarında yem torbalarının aynı anda (saatine veya yapılan uyarıya göre) takılmasıydı. Troilo böyle yapılmadığı takdirde atların huysuzlanabileceğini ve kargaşa çıkabileceğini belirtmiştir (Troilo, 1676: 556).

\section{Kervancı Otelleri: Kervansaraylar}

Kervansarayların hangi planda inşa edildikleri veya yolcuların buralarda nasıl ağırlandıkları hakkında birçok çalışma bulunduğundan ve bu çalışmanın doğrudan alanına girmediğinden, bu kısımda yalnızca kervansarayların güvenlik konusundaki durumları ele alınmaktadır. Belli mesafelerde kurulan ${ }^{25}$ kervansaraylarda yolcuların temel ihtiyaçları ücretsiz olarak karşılanmaktaydı. ${ }^{26}$ Selçuklular döneminden itibaren bir sisteme oturtulan bu hizmetler arasında yolcuların barınma, yeme içme, tedavilerinin yapılması ve garibanların giydirilmesi uygulaması da vardı (Tabakoğlu, 2014: 173; Eryavuz, 2002: 300). Zira bu konuda “... Kervansaraylarda uygun yemekler veriliyor ve yolcular kervansaraydan ayrılırken keselerinden hiçbir şey çıkarmadan kapıcıya teşekkür etmekle yetiniyorlar" diyen Tavernier, bu durumu açık bir şekilde izah etmiştir (Tavernier, 2010: 142).

${ }^{24}$ Konya civarında olduğunu düşündüğümüz bu yer tespit edilememiştir.

${ }^{25}$ Kervansaraylar ihtiyaçlar arttıkça ve ticaret geliştikçe daha çok ihtiyaç duyulmuştur. Anadolu Selçuklu Devleti döneminde hayli gelişen bu yapılar ortalama 30-40 km aralıklarla inşa edilmiştir (Orhonlu, 1984: 142).

${ }^{26}$ Anadolu'da ilk kervansaraylar II. Kılıç Arslan (1155-1192) döneminde yapılmıştır. 1243 yılından önce Anadolu'da 40 kadar kervansaray vardı. Moğolların bölgeye hâkimiyeti döneminde de kervansaraylara yenileri eklenmiştir (Tabakoğlu, 2014: 173). 
Kökenleri askeri amaçlı kurulan Ribatlara dayandığı düşünülen kervansaraylar (Eryavuz, 2002: 299-300) gerek yüksek duvarları gerekse tek bir kapıdan girilebilen mimari özelliğe sahip olmaları sebebiyle dış tehlikelere karş1 korunaklı yapılar olarak inşa edilmiştir. Yolların konumuna göre 30-40 km aralıklarla dizilmiş olan bu yapılar, genellikle şehir dışında kurulmakla beraber şehirlerde de yapılabilmekteydi. Kervanlar ise ekseriyetle şehir dışındaki kervansaraylarda kalmayı tercih ediyorlardı. Çünkü bunlar daha geniş ve bütün kervanın insan, hayvan ve mallarını alabilecek durumdaydı (Tavernier, 2010: 142-143). Bu husus bütün kervanın güvenli olarak kapalı bir sistem içinde muhafaza edildiğini ayrıca kalabalık veya dar sokakları olan şehirlerde zaman kaybetmediklerini göstermektedir. Bundan başka kervancılar kalmak için şehirlerdeki kervansaray veya hanları tercih etmeleri durumunda kendileri dışında şehir ahalisine de sıkıntı yaşatabilirlerdi. Neticede yüzlerce hayvan ve insanın herhangi bir şehre beraberce girmesi birçok öngörülemez tehlike ve sıkıntının ortaya çıkmasını kaçınılmaz kılabilirdi.

Kervansaray seçiminde etkili olan faktörler sadece büyüklük veya şehrin neresinde bulunduğu meselesi değildi. Ayrıca konumu gereği yaşanabilecek sıkıntılar da göz ardı edilmiyordu. Örneğin Tavernier Bitlis'te bulunan iki kervansarayın durumlarını şöyle mukayese etmiştir: "kervansarayların biri kentin eteğinde, diğeri kentin dişında; tüccarlar daha çok kentin dişındakinde kalmayı yeğliyorlar. Çünkü yakınlardaki dağlardan inen ve sokaklardan geçen beş-altı çay kabardığında, kent içindeki kervansaray bir anda su ile doluyor." (Tavernier, 2010: 289)

Kervansarayların güvenliği yapının korunaklı inşa edilmesinin yanı sıra nasıl güvenlik tedbirlerinin alındığıyla da ilgiliydi. Gece olunca kervansarayın dış kapısı kapatılır ve çevresindeki bekçiler de sabaha kadar bu yapıyı korurlardı (Tavernier, 2010: 143). Bu durum kervansaraylarda hırsızlık olaylarının görülmediği anlamına gelmemektedir. Örneğin Thévenot'un Urfa'daki kaldığı kervansarayda kendi ifadesiyle "gözü kara" ve "kurnaz" bir hırsız yolculardan birinin kaftanını çalmış ve kaçmış, olay subaşına iletilmesine rağmen hırsız yakalanamamıştı (Thévenot, 1693: 63). Kervansaraylarda hırsızlara karşı alınan diğer bir önlem davulculardı (Orhonlu, 1990: 68). Bu uygulama kervansaraylardan daha çok belli başlı yerlere -özellikle yüksek yerler tercih edilmekteydi- yerleştirilen nöbet kulübelerindeki nöbetçilerin kullandıkları "Derbend davulu" adlı davullar vasitasıyla yapılmaktaydı (Halaçoğlu, 1994: 163). Kervansarayların bazıları aynı zamanda derbend olduğu var sayılırsa hepsi için olmasa bile bazılarında uygulandığı söylenebilir. 
Kervansaraylar kalabalık kervanları alabilecek şekilde inşa edilmelerine rağmen iki kervan aynı anda konaklamak isterse yer sorunu çıkabiliyordu. Moncony, Öküz Mehmet Paşa tarafindan yaptırılan kervansaraya ${ }^{27}$ kendilerinden önce surre alayının kervanı yerleştiğinden yer bulmakta sorun yaşadıklarını şu sözlerle açıklamaktadır:

"16'sında gerçekten çok soğukta seyahat ederek Vezir Mehmet Paşa'nın yanında cami ve pazarıyla beraber küçük bir köy görünümündeki hanına geldik. Ancak Mekke kervanı bizden önce yüklerini boşaltarak hana yerleşmişlerdi. Bize de soğuğun altında ve çimlerin üzerinde konaklamak kaldl. Ateş yakarak bu zorluğa bir nebze katlanabildik. Maalesef gece olunca tacirlerin bir klsim mallarlyla bir at çalındl." (Monconys, 1697: 368)

\section{Yöreye Göre Giyim ve Yörenin Dilini Bilme}

Yöreye göre değişen kılık kıyafet dışarıdan bakan insanların ilk dikkat edeceği husus olduğundan içinden geçilen toplumun değer yargılarına ve kültürüne göre giyinmek öngörülemeyen sorunları bertaraf edebileceği gibi birçok kolaylık da sağlamaktaydı. Tavernier bu konuda yaptığı birçok yolculuk sonunda çıkardığı yarg1; yöreye göre giyinilmediği takdirde gezgin veya tacirin casus olarak görülme ihtimaliydi. Bunun için "Türkiye'de Türk, Iran'da Acem" gibi giyinmek gerekmekteydi. Seyyah bu bölgelerde en ufak bir şeyin valileri kuşkulandırarak casus ilan edilmeye kadar varacağı uyarısını yapmaktadır (Tavernier, 2010: 174). Tebdil-i kıyafet hususuna değinen diğer bir seyyah olan Simeon, kendisine bu konuda tembihte bulunan kişiyle geçen diyaloğunu şöyle aktarmaktadır: "Vardapet beni çok iyi karşıladı ve yanında iki hafta kaldım. Bana: 'Beygirini sakn beraber alma, onu burada benim yanıma birak, sen de giysilerini çıkar ve çul giy..." (Simeon, 2016: 129).

Seyyahlar geçtikleri yerlerde sıkıntı çekmemek için yanlarında Türkçe, Arapça, Kürtçe veya Ermenice bilen bir rehber tutarlardı. Nitekim Simeon Harput taraflarından Kürtçe ve Ermenice bilen bir Süryani rehber eşliğinde seyahat etmişti (Simeon, 2016: 130). Özellikle Ermenice bilen birisiyle yaptığı yolculuk yolda karşılaşacağı sıkıntılardan ziyade Ermeni kiliselerine yaptığı ziyaretlerde daha iyi anlaşmak içindi. Bu örnekler büyük bir kervana dâhil olunduğu zamanlar için değil, bilakis küçük bir grupla veya yalnız çıkılan yolculuklarda karşılaşılan durumlar için geçerlidir.

${ }^{27}$ Konya-Adana yolu üzerinde Niğde'nin Ulukışla ilçesinde bulunan kervansaray, 1619 tarihinde Osmanlı Sadrazamlarından olan Damad Öküz Ahmed Paşa tarafından yaptırılmıştır (Çobanoğlu, 2007: 27). 


\section{Gümrük Vergileri}

Yollarda güvenliğin sağlanması kadar önemli olan diğer bir husus Anadolu'nun bazı geçiş bölgelerinde ödenen ve "bâc-1 ubûr" olarak da adlandırılan iç gümrük vergileriydi. Devlet bilhassa doğu-batı eksenli yüksek değerli malların ticaretinde bu yolla hazineye düzenli bir gelir sağlamaktaydı. ${ }^{28}$ Bursa, Erzurum, Tokat, Diyarbekir gibi büyükşehirlerin yanı sıra bazı küçük yerlerde de gümrük vergileri alınmaktaydı (Kütükoğlu, 1996: 263). Gümrük noktalarından geçen kervanlara mensup kişiler hayvan başına veya duruma göre mal üzerinden vergilendirmeye tabi tutulurlardı. Tavernier kendisinin Fransız vatandaşı olduğu için bu vergilendirmeden muaf tutulduğunu kaydetmişse de (Tavernier, 2010: 123) bazı yerlerde vergi ödediğini yazmıştır. Ayrıca ona göre eğer İran'dan gelen Hristiyan tebaa herhangi bir gümrük bölgesinde vergi ödediyse başka bir yerde daha vergi ödemek zorunda değildi (Tavernier, 2010: 126). Osmanlı Devleti'nin yabancı devletlere verdiği ahitnamelerde göre ticaretle uğraşan müste'menler ithal ettikleri malların vergisini ilk gümrükte verdikten sonra diğerlerinde ödeme yapmazdı (Kütükoğlu, 1996: 264). Gümrüklerden geçerken yapılan ödemeler karşıllğında makbuz alınması gerekmekteydi. Böylece bu vergiyi tekrar tekrar ödemekten kurtulmuş olunuyordu. Bu duruma muhalif uygulamalar görüldüğünde gerekli uyarılar yapılmaktaydı. Örneğin İran'a gidiş gelişinde Van ve Bitlis'ten geçen tüccarın gümrük vergisini sınırda ödemesine rağmen, Diyarbekir'e bağlı Ziriki sancakbeyi ile Van'a bağlı Mahmûdi sancakbeyinin geçiş vergisi alması üzerine Van beylerbeyinden bu duruma engel olması istenmiştir (BOA. A.DVNSMHM.d., 14, 333). İç gümrüklerde alınan verginin başka gümrüklerde tekrar alınması sonraki dönemlerde de yaşanabilmekteydi. Örneğin 1802 yılında Siverek taraflarından getirilen duhan (tütün) vergisi yerinde ödenmişken tüccardan getirdiği tütün için Maden'de tekrar vergi alınmıştır (BOA. C..ML.. 16, 724, 1).

Tavernier gümrük geçişlerinde ne kadar ücret ödendiğini de kaydederek geçişlerdeki vergi farklarını ortaya koymuştur. Örneğin, Urfa ile Diyarbekir arasındaki her at için dört kuruş vergi ödenirken, Siverek'te de her at başına yarım kuruş alınıyordu. Diğer gümrük yeri olan Batman'da her at için bir kuruş, Hazro'da ise dörder kuruş ödeme yapılıyordu (Tavernier, 2010: 286-288).

\footnotetext{
${ }^{28}$ Bir süre önce önem kazanmaya başlayan yeni deniz yollarına kaymaları önlemek, İran ipeğinin Avrupa'ya taşınmasında temel rol oynayan İpek yolunu canlı tutmak gibi etkenlerden dolayı yabancılara 16. yüzyılın ikinci yarından itibaren ortalama $\% 3 \mathrm{e}$ tekabül eden gümrük vergisi uygulamaktaydı. Daha geniş bilgi için bk. (İnalcık, I, 2012: 314-318; Tabakoğlu, 2014: 370)
}

[2110] 
Bitlis'te at başına beş kuruş ödendikten sonraki menzil olan Tatvan'da da iki kuruş ödenmekteydi ${ }^{29}$ (Tavernier, 2010: 291).

Gümrük vergilerinin haricinde yolcular tehlikeli yerlere kurulan derbendler için de "geçiş akçesi" denen paralar ödemek durumundaydılar. Geçen sürülerden koyun başına alındığı gibi tüccar yüklerinden de alınan miktarlar derbendcilerin önemli gelir kalemlerinden birisiydi (Halaçoğlu, 1994: 163).

Simeon'un iddiasına göre Muş taraflarında gümrük bölgesinden geçerken bölgenin yabancısı olmasından dolayı subaşını kendisinden daha fazla gümrük vergisi talep etiğini şöyle aktarmaktadır: "Subaşı, Kuars'ta ${ }^{30}$ beni görünce: 'Bu adam nerelidir?' diye sordu. Arkadaşım: 'Sivas 'tandır' dedi, fakat o: Yalan söylüyorsun o İstanbulludur, buralardan olmadiğ iç̧in on kuruş vermelidir' dedi. Başkalarından iki rub alınırdı; fakat Ermeniler beni güç halle bir kuruşa kurtardılar." (Simeon, 2016: 132). Simeon'un iddiası ispata muhtaç olmakla beraber, arşiv kayıtlarında bazı gümrük bölgelerinde fazladan vergi alınmaması konusunda merkezden yapılan uyarılar mevcuttur. Örneğin Erzurum Hasankale'de İran'dan gelen kervandan fazla vergi talep edilmesi üzerine gerekli önlemlerin alınması için ferman yollanmıştır (BOA. TS.MA.e, 887, 62). Başka bir belgede Diyarbekir-Van arasındaki beyler ve kadılar gümrük vergisi dışında hediye (pişkeş) adı altında para talebinde bulunulmaması konusunda uyarılmışlardır (BOA. A.DVNSMHM.d., 79, 1219). Yine Şaki Abbas, oğlu ve bir kısım eşkıyanın gelip geçen kervanlardan gümrük vergisi adı altında para topladığı merkeze bildirilmiştir (BOA. AE.SMMD.IV.17,1836).

Bazı gümrük yerlerinden olması gerekenden fazla vergi talebinde bulunulsa da seyahatnamelerde bu konuda çok az sayıda olumsuz örnek verilmiş olması bu konuda pek fazla sıkıntı çekilmediğini göstermektedir.

\section{Resmi Evraklar}

Yolculuk yapmak için günümüzde ihtiyaç olan evraklar gibi yüzyıllar öncesinden de yolcunun yanına alması gereken resmi kâğıtlar mevcuttu. Yolcunun elindeki belgenin kapsamı oranında yolculuğun rahat geçmesi söz konusuydu. Babıâli'den alınan ve pasaport yerine geçecek bir ferman elde eden

${ }^{29}$ Gümrükler arasında görülen farklar sadece bu bölgeye ve yüzyıla mahsus değildi. Nitekim 16. yüzyılda iskelelerde de farklı ödemelerin alındığı görülmekteydi. Örneğin İmroz'da yüz akçe değerindeki bir maldan dört akçe, Limnos Adası'nda beş akçe alınırken, aynı tarihte Limanhisar iskelesinde aynı maldan dört akçe alınmaktaydı. Malın cinsine göre bu farklar tam tersi olarak da uygulanabilmekteydi (Çevik, 2004: 12-13).

30 Burasının günümüzdeki karşılığı bulunamamıştır. Ancak seyyahın Muş civarında olması Kuars'ın da Muş'a yakın bir yerleşim yeri olabileceği kanaatini oluşturmuştur. 
eczacı Tournefort bütün yolculuğu boyunca bu belge ile çok rahat bitki toplama salahiyeti elde etmişti. 9 Mayıs 1701 tarihinde düzenlenen fermanda seyyaha hiçbir şekilde olumsuz davranış sergilenmemesi, işini yapmasına engel olunmaması ve her türlü kolaylığın sağlanması hususları şüpheye mahal vermeyecek ölçüde açıkça belirtilmişti. Tournefort bu belgenin yanında Fransa büyükelçisinin Osmanlı sınır eyaletlerinin beylerbeylerine yazılmış tavsiye mektuplarının da alınması gerektiğini vurgulamıştır (Tournefort, II, 2005: 132). Yine Della Valle Halep'ten İskenderun'a geçerken Venedik' in konsolosundan bir tavsiye mektubu almıştı. Seyyah ancak bu şekilde İskenderun'dan gemiye binebileceğinden bahsetmiştir (Valle, IV, 1674: 199-200).

Tacirler dışında diplomatik bir heyetle yolculuğa çıkmış olan seyyahların bulundukları heyete mahsus verilen izinler, bu kişilerin heyetleri ile birlikte olmak kaydıyla seyahat etmelerine imkân sunmaktaydı. Ayrıca devlet tarafından elçilerin yanlarına verilen görevliler onları să̆ salim götürmek vazifesini üslenmekle beraber, onlar da "mürur" veya "yol emri" şeklindeki pasaport yerine geçebilen bir de belge taşımaktaydılar. Her ne kadar seyahatnamelerde pasaport olarak geçse de Osmanlı Devleti'nin verdiği belgeler zikredildiği gibi "yol emri" şeklindeydi. 1606 yılındak Leh Kralı'nın adamlarına verilmesi istenen yol emri ile 1572 yılında Viyana'dan yola çıkan kralın adamları olmalarından dolayı yolda herhangi bir sıkıntı yaşatılmaması hakkında Budun çavuşlarından Hasan'a emir verilmesi bu hususları teyit eden vesikalardan birkaçıdır (BOA, A.DVNSMHM.d., 78, 1835; BOA, A.DVNSMHM.d., 16, 206).

\section{SONUÇ}

Bu çalışmada 17. yüzyılda Anadolu yollarında seyahat eden yolcuların hangi zorluklarla karşılaştıkları ve karşılaştıkları problemlere nasıl çözümler ürettikleri üzerinde durulmuştur. Söz konusu sıkıntı ve tehlikelerin boyutları büyük oranda bu yollardan geçen ve olaylara bizzat şahitlik eden seyyahların eserleri çerçevesinde incelenmiştir.

Yollarda karşılaşılan tehlike ve problemler; eşkıyalık ve hırsızlık başta olmak üzere, yolun durumu, iklimsel özellikler, kişisel donanım, yöreye göre hareket etme zorunluluğu ve resmi evrakların tam olması gibi birçok başlık altında toplanmaktadır.

Yollardaki en ciddi tehlikelerin başında gelen eşkıya ve hırsızlar bölgelere göre dağılmış vaziyetteydiler. Doğu Anadolu'da Kürt eşkıyası, Güney Anadolu'da Arap ve Türkmen eşkıyası, Orta Anadolu'da Türkmenler ile Konargöçer eşkıyalar ve Batı Anadolu'da kapısız levendlerin yoğun olarak eşkıyalık 
hareketlerine giriştikleri görülmekteydi. Arazinin sarp yapısı ile rakımı yüksek geçitler ve dar yollar eşkıyaların kervanları yağmalamaları için bulunmaz firsat vermekteydi. Ana yollarda dahi bazı yerler acele geçilmesi veya teyakkuz halinde olunması gereken tehlikeli bölgeler barındırmaktaydı. Bu tehlikelere karşı bölgedeki derbendlerin korumasının dışında, kalabalık bir kervana dâhil olmak, parayla muhafiz tutmak, vakitlice gidilecek yere varmak, daima hazırlıklı olmak, korunaklı bir kervansarayda gecelemek, çevreyi bilen ve bölgenin dilini bilen tecrübeli bir rehber eşliğinde yolculuk yapmak gibi önlemler hayati derecede önemliydi.

Eşkıya ve hırsızlar dışında yolcuların dikkat etmesi gereken hususların başında yolculuk yapılacak mevsim ile günün hangi saatinde yola çıkılacă̆ı sorunu vardı. Büyük bir kısmı bahar ve yaz mevsiminde yapılan yolculuklarda, özellikle geceleri yol almak daha çok tercih edilen bir yöntem olduğu anlaşılmıştır. Kış şartlarında soğuk, kuru rüzgâr, don ve kar olayları büyük sorun teşkil ederken, bahar dönemlerinde yoğun yağmur ve bunların ortaya çıkardığg çamurlar yolları çekilmez kılabiliyordu. En çok seyahat edilen yaz dönemleri ise güneş yakması, susuzluk gibi ciddi problemlere sebep olduğu için bilhassa daha serin olan gece yolculuğu tercih sebebiydi.

Yolculuklarda tehlikeden kaçmanın temel kuralı kalabalık ve iyi organize olmuş bir kervanla yolculuk etmekti. Ancak bu kervanlarla yapılan yolculuklarda bazı şeylerin temini de büyük problemlere sebep olabiliyordu. Örneğin yolda yemeği pişirecek odun bulmak, menzillere varıldığında su sırası bekleme, hayvanların otlayacağı büyük alanların tespiti, hatta hayvanlara aynı anda yem verilmediğinde ortaya çıkabilecek kargaşa bile küçük gibi gözüken ciddi problemler arasındaydı. Az sayıda kişiyle yapılan yolculuklar ise hırsız ve eşkıyalara davetiye çıkartmak anlamına gelebiliyor veya akşam sineklerden korunmak için yakılan bir ateş bile hırsızlara konaklanan yerini gösterebiliyordu. Büyük bir kervana katılmayanlar, geçtikleri topraklarda haksız gümrük veya pişkeş uygulamalarına tabi olabiliyorken, böyle şeylerin önünü almak için iyi bir rehber yanında yöreye göre giyinmek ve mümkünse yörenin dilini bilmek yolculuğun daha rahat geçmesini sağlayabilmekteydi.

Sonuç olarak 17. yüzyılda Anadolu'da yapılan yolculuklar çok yönlü tehlikeleri ve problemleri içinde barındıran meşakkatli bir süreçti. Ancak yollarda çekilen sıkıntılar, Anadolu yollarına belli aralıklarla yapılan kervansaray, derbend ve menzil teşkilatları gibi güvenlik mekanizmaları, isyan iklimin hüküm sürdügü bu asırda bile kesintisiz yolculukların yapılmasını mümkün kılmıştır. 


\section{Emrah İSTEK}

\section{KAYNAKÇA / REFERENCES}

Abdurrahman, A. P. (2008). Abdurrahman Abdi Paşa Vekâyi'-nâmesi. Çamlıca yayınları.

Aleppo, P. O. (1836). The Travels of Macarius, Patriarch of Antioch (Cilt 9).

Akdağ, M. (1995). Türk Halkının Dirlikve Düzenlik Kavgası Celali İsyanları. Cem yayınevi.

Andersen, J., Iversen, V. \& Olearius, A. (1669). Orientalische ReiseBeschreibunge: Jürgen Andersen aus Schleßwig der An. Christi 1644 außgezogen und 1650 wieder kommen und Volquard Iversen aus Holstein so An. 1655 außgezogen und 1668 wieder angelanget. Holwein.

Aykut, N. (1994). Dilaver Paşa. TDV Íslam Ansiklopedisi, 9, 297.

Bilgin, A. \& Bozkurt, F. (2010). Bir malî gelir kaynağı olarak vârissiz ölenlerin terekeleri ve beytülmâl mukataaları. Kocaeli Üniversitesi SBE Dergisi (20), 1-31.

BOA. A.DVNSMHM.d., 14, 333 (20.02.978).

BOA, A.DVNSMHM.d., 16, 206 (07.11.979).

BOA, A.DVNSMHM.d., 78, 1835 (18.05.1018).

BOA. MHM.d., 79, 1099 (12.10.1019).

BOA. MHM.d., 79, 1219 (05.01.10120).

BOA. MHM.d., 79, 722 (06.04.1019).

BOA. MHM.d., 79, 920. (27.10.1019).

BOA. MHM.d., 87, 238 (11.12.1046).

BOA. MHM.d., 88, 318 (29.10.1047).

BOA. MHM.d., 98, 136 (20.02.1100).

BOA. MHM.d., 102, 424 (10.04.1103).

BOA. MHM.d., 112, 81 (10.05.1113).

BOA. TS.MA.e, 887, 62 (10.08.1059).

BOA. AE. SAMD. III, 18, 1718 (24.03.1021).

BOA. C. ML. 16, 724, (11.07.1217) 
Anadolu Kervan Yollarında Karşılaşılan Problemler ve Yol Güvenliği (17. YY)

BOA. AE. SMMD. IV.17,1836 (10.06.1091).

Cezar, M. (1965). Osmanlı Tarihinde Levendler. Çelikcilt matbaası.

Çevik, Z. (2004). Osmanlı İmparatorluğu'nda Gümrük. SDÜ Fen-Edebiyat Fakültesi Sosyal Bilimler Dergisi, 10, 9-20.

Çobanoğlu, A. V. (2007). Öküz Mehmed Paşa külliyesi. TDV İslam Ansiklopedisi, 34, 27-28.

Eryavuz, Ş. (2002). Kervansaray. TDV Íslam Ansiklopedisi, 25, 299-302.

Evliya Çelebi b Derviş Mehemmed Z1ll. (2011). Evliya Çelebi Seyahatnamesi, 5, (Kahraman S.A., Dankoff R. vd. Haz.). Yapı Kredi Yayınları.

Suraiya, F. (1995). Hacllar ve Sultanlar (1517-1638). Tarih Vakfı yurt yayınları

Halaçoğlu, Y. (1994). Derbend. TDV İslam Ansiklopedisi, 9, 162-164.

İlgürel, M. (2003). Levent. TDV İslam Ansiklopedisi, 27, 149-151.

İnalcık, H. (2012). Devlet-i Aliyye. Osmanlı Imparatorluğu Üzerine Araştırmalar-I. Türkiye İş Bankası Kültür yayınları.

İnalcık, H. (2015). Devlet-i Aliyye. Osmanl Imparatorluğu Üzerine Araştırmalar-III. Türkiye İş Bankası kültür yayınları.

Jorga, N. (2017). Osmanlı Imparatorluğu Tarihi (Cilt 4). Yeditepe yayınları.

Kocaoğlu, B. (2020). Osmanlı Ordusu'nda Kılavuz Kullanımına Genel Bir Bakış (XVIII. Yüzyılın Ortalarından XIX. Yüzyılın Başlarına Kadar). Geçmişten Günümüze Tarih Araştırmaları, (Mutlu Adak Ed.), Gazi kitabevi, 47-69.

Kütükoğlu, M. S. (1996). Gümrük. TDV İslam Ansiklopedisi, 14, 263-268.

Kütükoğlu, M. S. (2018). Osmanlı'nın Sosyo-Kültürel ve İktisâdi Yapısı. TTK.

Monconys, B. d. (1697). Des Herrn de Monconys ungemeine und sehr curieuse Beschreibung Seiner Jn Asien und das gelobte Land, nach Portugall, Spanien, Jtalien, in Engelland, die Niederlande und Teutschland gethanen Reisen. Andreas Zeidlern.

Müderrisoğlu, M. F. (2002). Menzil Kavramı ve Osmanlı Devleti'nde Menzil Yerleşimleri. Türkler Ansiklopedisi, 10, 920-926.

Naîmâ. (2007). Târih-i Na î̀mâ. (M. İpşirli, Dü.). TTK.

Orhonlu, C. (1963). Osmanlı İmparatorluğu'nda Aşiretleri İskan Teşebbüsü (1691-1696). Edebiyat Fakültesi Basımevi. 
Orhonlu, C. (1984). Osmanlı İmparatorluğu'nda Şehircilik ve Ulaşım Üzerine Araştırmalar. (S. Özbaran). Ege Üniversitesi Edebiyat Fakültesi yayınları.

Orhonlu, C. (1990). Osmanlı Imparatorluğu'nda Derbend Teşkilatı. Eren yayıncilik.

Önkal, A. Bozkurt, Ö. (1994): Deve. TDV İslam Ansiklopedisi, 9, 222-226.

Pamuk, Ş. (2002). Kuruş. TDV İslam Ansiklopedisi, 26, 458-459.

Pehlivanlı H. http://www.pusulagazetesi.net/koseyazilari/osmanlilarda_yol_ emniyeti-1242.html, Erişim tarihi: 07.06.2020.

Sak, İ. Çetin C. (2004). XVII. ve XVIII. Yüzyıllarda Osmanlı Devleti'nde Menziller ve Fonksiyonları: Akşehir Menzilleri Örneği. Selçuk Üniversitesi Türkiyat Araştırmaları Dergisi, 16, 179-221.

Simeon, P. (2016). Polonyalı Bir Seyyahın Gözünden 16. Asır Türkiyesi. (H. D. Andreasyan, Çev.). Köprü Kitap Yayınevi.

Tabakoğlu, A. (2014). Türkiye İktisat Tarihi. Dergah yayınları.

Taeschner, F. (2010). Osmanlı Kaynaklarına Göre Anadolu Yol Ă̆g. (N. Epçeli, Çev.). Bilge kültür sanat yayınları.

Tavernier, J.-B. (2010). Tavernier Seyahatnamesi. Kitap yayınevi.

Thévenot, J. (1693). Der Morgenländischen Reisen des Herrn de Thévenot. Gedruckt und Verlegt durch Philipp Fievet.

Thévenot, J. (2009). Thévenot Seyahatnamesi. (A.Berktay, Çev.). Kitap yayınevi.

Tournefort, J. d. (2005). Tournefort Seyahatnamesi (Cilt 2). (A.B. Tunçdoğan, Çev.). Kitap yayınevi.

Troilo, F. F. (1676). Orientalische Reisebeschreibung.

Tuncer, O. C. (2007). Andolu Kervan Yolları. Vakıflar genel müdürlüğü yayınevi.

Turan, O. (2017). Selçuklular Zamanında Türkiye. Ötüken Neşriyat.

Ulusoy, Ç. (1944). 17. Asırda Saruhan'da Eşkıyalık ve Halk Hareketleri. Resimli Ay matbaas1.

Valle, P. D. (1674). Der Pilgram Reiss-Beschreibung in die Orientalische Laender (Bd. IV). In Verlegung Johann-Hermann Wiederholds.

Yıldız, H. D. (1992). Berberîler. TDV İslam Ansiklopesi, 5, 478-483. 